\title{
Federated States of Micronesia
}

\section{ARTICLE IV CONSULTATION}

Under Article IV of the IMF's Articles of Agreement, the IMF holds bilateral discussions with members, usually every year. In the context of the 2012 Article IV consultation with the Federated States of Micronesia, the following documents have been released and are included in this package:

- The staff report for the 2012 Article IV consultation, prepared by a staff team of the IMF, following discussions that ended on November 19, 2012, with the officials of the Federated States of Micronesia on economic developments and policies. Based on information available at the time of these discussions, the staff report was completed on December 20, 2012. The views expressed in the staff report are those of the staff team and do not necessarily reflect the views of the Executive Board of the IMF.

- A Public Information Notice (PIN) summarizing the views of the Executive Board as expressed during its January 14, 2013 discussion of the staff report that concluded the Article IV consultation.

- $\quad$ A statement by the Executive Director for the Federated States of Micronesia.

The document listed below will be separately released.

Statistical Appendix Paper

The policy of publication of staff reports and other documents allows for the deletion of market-sensitive information.

Copies of this report are available to the public from

International Monetary Fund $\bullet$ Publication Services

$70019^{\text {th }}$ Street, N.W. $\bullet$ Washington, D.C. 20431

Telephone: (202) 623-7430 • Telefax: (202) 623-7201

E-mail: publications@imf.org Internet: http://www.imf.org

International Monetary Fund

Washington, D.C. 


\section{INTERNATIONAL MONETARY FUND}

\section{FEDERATED STATES OF MICRONESIA}

\section{STAFF REPORT FOR THE 2012 ARTICLE IV CONSULTATION}

December 20, 2012

\section{KEY ISSUES}

Economic Environment. The economy continued to expand last year, albeit at a slower pace than in previous years. Growth in FY2012 is estimated at 1.4 percent, down from 2$2 \frac{1}{2}$ percent for $\mathrm{FY} 2010-11$ as recent construction projects are winding down. A modest fiscal surplus of $1 \frac{1 / 4}{4}$ percent is expected in FY2012 thanks to high fishing fee revenue.

Outlook and Risks. Economic growth will likely slow in the near term, as the private sector falls short of offsetting a decline in public sector demand from scheduled Compact grant reductions. While the fishery sector is expected to continue its healthy expansion, lackluster wholesale and retail activities will remain a drag on private sector growth. Risks to the outlook are on the downside, with spillovers from possible further deterioration of global growth prospects and commodity price shocks outweighing upside risks from the U.S. military base upgrading projects in Guam and an accelerated release of delayed infrastructure grants.

Fiscal Sustainability. Achieving long-term budgetary self-reliance is becoming more urgent as FY2023 approaches when the annual Compact grants are set to expire. Closing the revenue gap would require a fiscal adjustment by $5-61 / 2$ percent of GDP over the medium term, depending on the pace of adjustment. Planned comprehensive tax reforms and expenditure cuts focusing on public wages would be major contributors to the necessary adjustment. Public sector financial management should be strengthened in tandem to safeguard benefits of fiscal reforms.

Private Sector Development. Weak private sector development continues to hold back sustainable economic growth. Reforms to ease the cost of doing business are key to boost potential growth and generate employment. The priorities should include further liberalizing land use and lease, and streamlining procedures related to investment permits both at national and state levels. The government should devise a nation-wide development plan to guide these efforts, building on the momentum created by the first Development Partners Forum held in the fall of 2012.

Financial Sector. The banking sector remains liquid, but contributes little to economic growth. Given the recent pickup in consumer lending, credit quality should be carefully monitored. The FSM Development Bank should be put under appropriate supervision and re-directed to its intrinsic role of providing capital funds to viable start-ups rather than directly competing with private banks over consumer loans. 
Approved By

Stephan Danninger and Masato Miyasaki
Discussions took place in Pohnpei from November 9-19, 2012. The staff team comprised with A. Yoshida (head), I. Saito, T. Dao (all APD), and Y. Yang (Regional Resident Representative). B. Karae (OED), L. Pan (World Bank), and H. Rijn (AsDB) participated in the discussions.

\section{CONTENTS}

INTRODUCTION

A. Fiscal Policy __ 6

B. External Stability and Exchange Rate __ 10

C. Private Sector 10

D. Financial Sector__ 11

E. Other Issues__ 12

$\begin{array}{ll}\text { STAFF APPRAISAL } & 12\end{array}$

\section{BOXES}

1. Fiscal Arrangements and Operational Challenges in Compact Grants Utilization ___ 14

2. The Challenge of Commodity Price Volatility on Inflation___ 16

\section{FIGURES}

1. From Crisis to Recovery-Rebuilding Policy Buffers 17

2. Economic Developments and Outlook 18

\section{TABLES}

1. Basic Data, FY2008-13 19

2. General Government Operations, FY2008-13 20

3. Indicators of Financial and External Vulnerability, FY2006-12_ 21

4. Balance of Payments, FY2008-13 _ 22

5. Medium-term Scenario (Current Policies), FY2009-17__ 23

6. Social Indicators__ 24

\section{APPENDIXES}

I. Risk Assessment Matrix __ 25

II. Long-term Fiscal Sustainability___ 26 


\section{INTRODUCTION}

1. The Federated States of Micronesia (FSM) is a small Pacific Island country highly dependent on external aid, mainly from the United States. ${ }^{1}$ A new Compact of Free Association Agreement with the United States ("Compact") effective since FY2004 ${ }^{2}$ continues to provide funding for infrastructure expenditure and administrative expenses, but transfers to the FSM are steadily declining and ceasing in FY2023. Thereafter, the FSM is expected to complement its domestic revenues with income from its Compact Trust Fund (CTF) and other savings.

2. The amended Compact has tightened rules on reporting, auditing, and the use of grants, which were initially difficult for the national and state governments to meet. Although infrastructure projects started to be implemented more smoothly in FY2009 as government agencies adapted themselves to the new rules, about $\$ 44$ million (15 percent of GDP) in infrastructure grants remains unused, even excluding another $\$ 28$ million (10 percent of GDP) that was returned to the pool of funds after once approved either due to cancellation or less than estimated costs (Box 1). The U.S. dollar is the official legal tender.

3. The Article IV discussions focused on policies to ensure long-term sustainability through strengthening fiscal management and promoting the private sector growth. The scheduled expiry of Compact grants in FY2023 poses a major challenge to continuation of public services at the current level. On the other hand, remoteness from major markets and the small scale of the economy makes it difficult to attract foreign investors and retain skilled workers. Outward migration continues to the United States where FSM citizens can work without a visa. In the absence of monetary policy and given the large fiscal adjustment needed over the medium term, the authorities have limited policy space to respond to external shocks. The government therefore needs to proceed with fiscal and structural reforms to secure fiscal sustainability, boost potential growth of the economy, and create sufficient policy space to dampen the effects of unforeseen developments.

\section{RECENT ECONOMIC DEVELOPMENTS AND OUTLOOK}

4. Since the last Article IV consultation, the economy continued on a steady growth path. Following a recession in FY2006-08 due to delays in Compact grants utilization as well as high fuel and food prices, the FSM economy grew by $2-2 \frac{1}{2} 2$ percent for FY2010 and FY2011. The expansion was driven by new construction activities, such as the airport renewal projects funded by the U.S. Federal Aviation Authority (FAA), and by growth of the fishery sector helped by good fishing conditions and high prices. The economy remains dependent on the large public sector (40 percent of GDP, including public enterprises), although there are signs of a further growth pick up in the fisheries and agriculture sectors. Inflation moderated from its FY2009 peak, and fluctuations are

\footnotetext{
${ }^{1}$ The FSM (with a population of about 102,000) has four states-Chuuk, Kosrae, Pohnpei, and Yap, each with its own executive and legislative bodies. Authority is highly decentralized, with state governments significantly larger than the national authority.

${ }^{2}$ The fiscal year runs from October to September (for example, FY2012 covers October 2011 to September 2012).
} 
largely driven by commodity prices (Box 2). After reaching 7.8 percent in FY2009, inflation has declined to 4.6 percent in FY2011. However, the last quarter of 2011 recorded a 6.5 percent increase (year-on-year) reflecting the rise in international food and fuel prices, which compose about 46 percent of the consumption basket. Increasing availability of consumer loans may have also contributed to a pick-up in inflation in recent years (see paragraph 34).

Selected Economic Indicators

\begin{tabular}{|c|c|c|c|c|c|}
\hline & FY2009 & FY2010 & FY2011 & $\begin{array}{l}\text { Est. 1/ } \\
\text { FY2012 }\end{array}$ & $\begin{array}{l}\text { Proj. } \\
\text { FY2013 }\end{array}$ \\
\hline & \multicolumn{5}{|c|}{ (Year-on-year Changes) } \\
\hline Real GDP & 1.0 & 2.5 & 2.1 & 1.4 & 0.8 \\
\hline \multirow[t]{2}{*}{ Consumer price index } & 7.8 & 6.3 & 4.6 & 5.6 & 4.2 \\
\hline & \multicolumn{5}{|c|}{ (In percent of GDP) } \\
\hline Consolidated fiscal balance & 1.6 & 0.5 & 0.6 & 1.2 & 0.8 \\
\hline Current account balance & -18.5 & -16.6 & -18.9 & -15.0 & -14.3 \\
\hline
\end{tabular}

5. The overall fiscal balance of the consolidated government recorded modest surpluses for three straight years through FY2011, with an uneven distribution of outcomes across states. In FY2011, the overall consolidated fiscal balance was $\$ 1.9$ million (0.6 percent of GDP) in surplus, helped by economic growth and stabilizing public wages. While Chuuk and Yap turned in a surplus in FY2011 with better revenue administration, Kosrae and Pohnpei each recorded deficits equivalent to about 1 percent of state GDP.

6. Public debt remains at a relatively low level, but underfunding in the CTF assets and declining balance of the social security fund pose long-term challenges. Gross public debt is relatively low at $\$ 87.1$ million (below 30 percent of GDP) in FY2011, mostly owed to the Asian Development Bank (AsDB) on concessional terms. The size of public financial assets held in the CTF is substantial at $\$ 257$ million (83 percent of GDP) as of end-FY2012. However, asset accumulation in the CTF is insufficient for the long-term budget self-reliance (see Appendix II). In addition, net assets of the social security fund declined from $\$ 42.4$ million in 2010 to $\$ 40.4$ million in 2011 with benefit payments still exceeding contribution revenue, continuing to raise concerns over the viability of the system (see paragraph 21).

7. Despite some deterioration of the current account balance (from -12 percent of GDP for FY2006-8 to -18 percent for FY2009-11 on average), external balance is sustained by a stable flow of official transfers. The majority of the overall current account deficit (18 percent of GDP for FY2009-11) is financed through capital transfers from official sources (12 percent of GDP). Given their contractual nature, they can be considered a stable source of funding. Similarly, imbalances within the current account balance (a trade and services deficit of 61 percent of GDP) are largely offset by a stable surplus in the income and transfer balances from Compact current grants and remittances (43 percent of GDP). Given the dedicated official funding sources, the level of gross international reserves (about $3 \frac{1}{2}$ months of imports) is not as much a critical indicator for the 
external sustainability as in other countries. The current account deficit widened in FY2011, with an increase in exports (mainly fish) more than offset by that in imports driven by construction materials and fuels. Visitor arrivals declined significantly in FY2011 to 20 percent below the FY2009 peak, while higher inflation than in trading partners has kept the real effective exchange rate at an appreciated level.

8. Financial conditions have remained tight. There are large spreads between deposit rates (around 1 percent) and loan rates (about 14 percent for consumer loans, about 7 percent for commercial loans), partly reflecting high risks involved in lending in the FSM, given limited availability of land as collateral. Commercial loan growth has been stagnant in recent years, while consumer loans saw some pick up. The ratio of consumer loans to household income is relatively high (about 24 percent in 2011).

9. Economic growth will likely slow in the near term, as the private sector falls short of offsetting the declining public sector demand from Compact grants reduction. Growth in FY2012 is estimated at 1.4 percent as recent construction projects financed through FAA grants are winding down. A modest consolidated fiscal surplus of 11/4 percent of GDP is expected in FY2012, mainly due to a sharp increase in fishing access fee revenue by $\$ 7.6$ million (21/2 percent of GDP). While the fishery sector is expected to continue its healthy expansion, lackluster wholesale and retail activities will remain a drag on the private sector growth.

10. Beyond the near-term, growth is weighed down by the scheduled reduction in Compact grants. In addition, the 2010 census shows that the population has been shrinking, and significant outward migration continues despite the reasonably good economic performance in recent years. Staff expects growth to stay low at about $1 / 2$ percent over the medium term, with limited private sector growth failing to offset the effects of a decline in Compact sector grants ( $\$ 0.8$ million per annum before adjusting for inflation).

11. Risks to the outlook are on the downside (see Appendix I, Figures and Tables). While there are certain upside risks from the U.S. military base upgrading projects in Guam (more demand for the FSM workers, goods and services) and possible acceleration in release of delayed infrastructure grants, larger risks are that further deterioration in the external environment and volatile commodity prices hold back growth, leading to further delays in fiscal adjustment, and thus elevating concerns over fiscal sustainability. Long-term risks include failure to fully prepare for the expiry of the Compact grants, continued outward migration of working age population, and climate change and the associated shore erosion of limited farmland. In order to better prepare for growth shock, strengthening the fiscal policy space should be explored (see paragraph 17). In the event exogenous shocks materialized, fiscal adjustment toward self-sufficiency could be temporarily eased or suspended as long as the medium-term target is maintained. To mitigate the impact of commodity price shock, possible long term measures to be considered include promoting domestic food supply through commercial farming (see Box 2).

\section{Authorities' Views}

12. The authorities generally agreed with staff projections for the FSM economy. They shared the view that medium-term growth prospects are diminished as a result of declining 
Compact grants, and the private sector does not have enough strength to compensate for it. They also agreed that risks to the outlook are on the downside, citing among others the vulnerability of the economy to commodity price shocks.

13. On fishing activities, the authorities acknowledged that, while fishing fees provide a valuable source of additional revenue for the public finance, it does not generate sufficient employment and income for the private sector in the FSM.

\section{POLICIES TO ACHIEVE SUSTAINABLE GROWTH}

\section{A. Fiscal Policy}

14. The projected amount of government assets is unlikely to generate sufficient income to replace expiring Compact grants in FY2023 (Appendix II). Notwithstanding the benign investment performance in FY2012, projected investment returns from the CTF in FY2024 will fall short of the Compact grants to be replaced by as much as $\$ 16$ million in FY2011 prices (about 5 percent of GDP). To achieve the long-term fiscal sustainability, the FSM needs a steady and decisive fiscal adjustment.

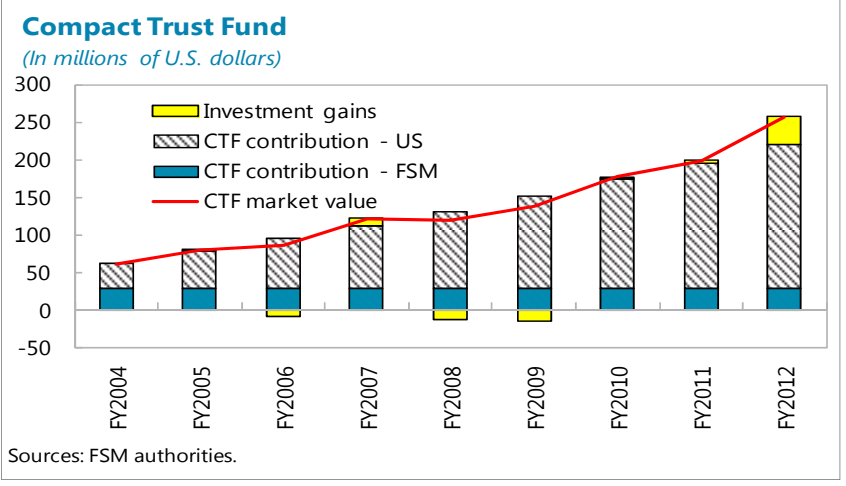

15. A new high-level initiative on achieving long-term sustainability provides an opportunity to thoroughly review the direction of policies. President Mori announced in March 2012 his intention to establish the "2023 Planning Committee" (the Committee) to undertake an assessment of the financial situation of the FSM in FY2024 onwards and develop a realistic action plan for addressing the looming budgetary shortfall, though it is unclear when Congress will approve the appropriation of budget for the establishment of the committee. In the draft FY2013 budget, the President proposed to contribute $\$ 1$ million to the CTF, but Congress did not approve such allocation.

16. There is considerable risk that the CTF would not reach the necessary level for selfsufficiency. Both the national and states government should agree to realistic plans of reform and start implementing them as soon as possible. In this light, approval of the budget for establishment of the 2023 Planning Committee is urgently needed.

17. The following four points should serve as the guiding principles for the Committee to meet its objectives of developing a credible long-term fiscal strategy.

$>$ Develop a realistic macroeconomic framework. Budget documents should cover the general government (include contingent liabilities from public enterprises or social security fund), and long-term fiscal projections should use conservative assumptions on growth and asset returns while providing an appropriate expenditure trajectory. The IMF stands ready to share its long- 
term fiscal projection framework to assist the government in preparation of their own projections.

> Devise a balanced fiscal adjustment path. The adjustment path should strike an appropriate balance between the need to preserve assets for future generation, current developments needs (for instance for infrastructure), and short-term growth implications of fiscal reforms.

Based on a 6 percent rate of return assumed in an earlier GAO study, achieving budgetary selfsufficiency requires financial assets in the CTF of $\$ 1.1$ billion in FY2023 (in FY2011 prices). This level could be achieved by increasing fiscal surplus to about 6.4 percent of GDP by FY2016, and then maintaining the surplus at that level until FY2023. Alternatively, to soften the growth impact the government could accumulate fiscal surpluses more gradually over a longer period; but this would require a higher overall fiscal surplus target and leave a shorter time to re-adjust the fiscal trajectory in the event of setbacks (see Appendix II); the longer adjustment would also pose a higher risk of reform fatigue. Regardless of the chosen path, the considerable growth impact of fiscal consolidation would need to be partly offset by accelerating structural reforms (see section ( below).

$>$ Build in policy buffers. Given the long implementation period, the absence of monetary policy, and the susceptibility of the economy and the poor to external shocks, the FSM needs to build fiscal policy space for the resilience of its medium-term plan. Possible policy actions include allocating part of expenditures to fund an emergency transfer program. In designing these arrangements, however, care should be taken that they do not undermine the long-term fiscal consolidation efforts, possibly by requiring that the amount should be recovered by other savings within a limited length of years once the temporary shocks subsided.

$>$ Secure buy-in of the public and state governments. The long-term fiscal consolidation cannot be carried out and sustained without broad public support. In addition, given the significant size of state governments in the FSM, their contributions to the fiscal adjustment are essential. It is thus imperative for the national government to engage these stakeholders into the discussion of needed fiscal reforms. From this viewpoint, the continuous enhancement of audits and the reflection of their results in fiscal management are also important.

Approval of a long-term fiscal reform plan should be the key deliverable of the Committee.

18. The government should immediately prepare fiscal expenditure reforms, especially to contain the public wage bill. Significant savings could be made by improving the operational efficiency of current and capital expenditure through better planning and coordination between national and state governments. Beyond such gains, there is room for reducing current expenditure as public wage rates for governments are on average 2.1 times higher than for the private sector. Those for public enterprises have even higher ratio of 2.8 times. While qualifications required for private and public sector may not be

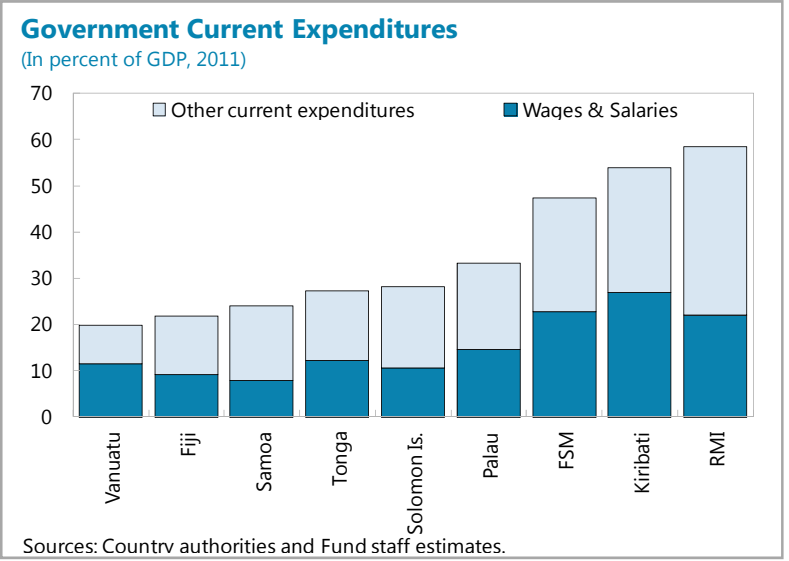


fully comparable and drastic cuts in public wages may risk accelerating outward migration, regional comparison of public wages (see text chart) suggests that there is room for reducing them as share of GDP without having too negative effect on the economy. Governance control by the government over compensation of public enterprises should be strengthened to ensure their wage level is justifiable from the viewpoint of job requirement.

19. In parallel, the planned comprehensive tax reform should be swiftly implemented. Enhancing revenue is imperative to put public finances on a more sustainable path. A set of bills to create the Unified Revenue Authority (URA) and to introduce a net profits tax (effective October 2013) and a value added tax (effective October 2014) in lieu of gross revenue and state sales taxes were approved by the national government as well as two out of the four state governments, but will not take effect until they are approved by all states. This reform will remove the bias against industries with relatively high fixed costs and distortions from different tax rates across goods and services, making the FSM tax system more efficient. Given the urgency of the tax reform, the national government should step up its efforts to engage state governments and the general public for swift consideration of the tax reform bill in the remaining states. Further efforts to strengthen the tax administration through staff training and upgrading of the IT system will also be necessary.

20. To complement and safeguard the benefits of expenditure and tax reforms, it is essential to improve public sector financial management. Ongoing efforts to strengthen financial management with support from the Pacific Financial Technical Assistance Center (PFTAC) should be accelerated in this respect: budget documents should reflect activities of the general government financed by domestic revenues and foreign grants as well as those of state governments. The mission also encourages the authorities to devise a fiscal rule requiring fiscal surpluses to be transferred to the CTF. Under the current system, fiscal surpluses in one year can be appropriated to finance next year's expenditure. Given the nature of the FSM as federated states, the long-term fiscal consolidation also requires strengthening the fiscal discipline at state level to contain expenditures, including through tighter fiscal rules on their use of the expenditure carry-over between annual budgets.

21. The social security system of the FSM remains in a challenging financial situation. It is financed by employer/employee contributions at a rate of 7 percent each paid to the system and funds benefit payments for the old-age, surviving spouses of deceased workers, and disabled. Despite some efforts in recent years to strengthen collection, total benefit payments ( $\$ 17.4$ million) were still in excess of total contributions (\$16.6 million) in 2011. Although the contributions rate was raised from 6 to 7 percent in 2010 and will be further increased to 7.5 percent in 2013, it is unlikely to halt the erosion of assets permanently. Further reforms of the benefit structure and tax collection are needed to reverse fund deficits and reduce delinquent accounts so as to bring the

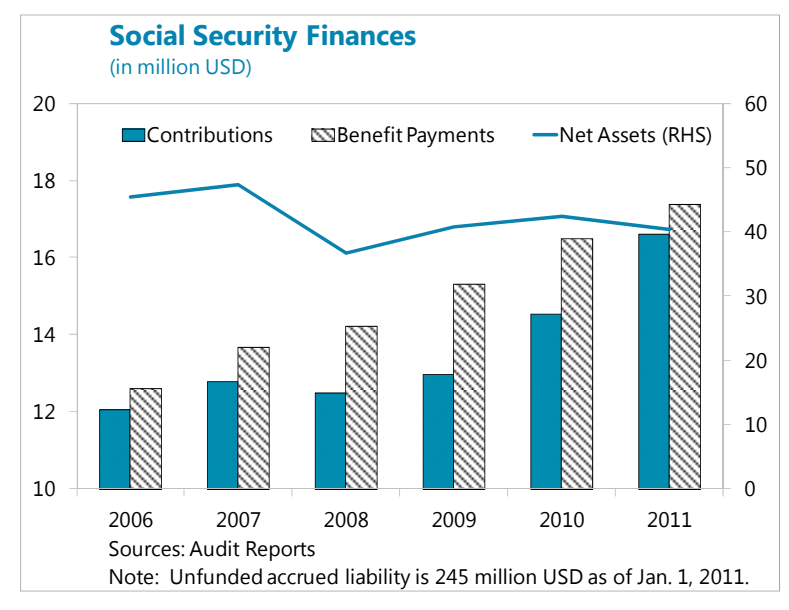


system into long-term sustainability. Given that it will take time to carry out comprehensive reforms, contributions from the general budget will likely be needed to protect the value of the social security fund.

22. Public enterprises pose another important fiscal risk. They have significant economic presence accounting for 8.6 percent of GDP. Though budget transfers to public enterprises are currently limited, utilities and other public service providers pose considerable contingent liabilities for public finances in the event of a deterioration of their financial positions. It is therefore critical to strengthen the oversight and accountability of public enterprises, in particular in electricity and telecommunication, which are critical services for private sector development.

\section{Authorities' Views}

23. The authorities did not specify a preferred pace of fiscal adjustment, partly because it did not want to preempt discussions in the 2023 Planning Committee. The government is currently considering expenditure cuts of 6 percent every three years, totaling around 20 percent, to accommodate the scheduled reduction in Compact grants. However, the authorities were willing to also review the staff's fiscal adjustment plan at the Committee including a more comprehensive reforms, not least because it appears difficult to protect critical public services in areas, such as health and education, under the current expenditure cut plan.

24. The authorities agreed on the need to contain the growth of wage expenditure. However, they noted that public and private sector wages are not necessarily comparable given different levels of competence and skill that are required. Staff reiterated that the aggregate public sector wages in the FSM are notably high as share of GDP among the regional peers.

25. Regarding policy buffer against external shocks, the authorities pointed out that they have a separate trust fund from the CTF whose assets are accumulated against the risk of natural disasters. They admitted, however, that use of those assets was limited to the purpose of disaster relief and available other funds were not sufficient to mitigate other costs, such as commodity price shocks.

26. The authorities agreed on the need for social security reform. With an increase in the contribution rate (from 7 percent to 7.5 percent) scheduled in January 2013, however, there are no immediate plans for improving the social security fund balance. For the time being, they will explore options for comprehensive reforms while continuing support from the general budget.

27. On public enterprises, the authorities pointed to the fact that operational subsidies from the government to public enterprises have been significantly reduced over the past several years. While there remain some capital subsidies, they argued, those are primarily used to support provision of essential services by public enterprises. 


\section{B. External Stability and Exchange Rate}

28. The FSM's real exchange rate has been appreciated since the global downturn. The real effective exchange rate appreciated by 9 percent in FY2009 due to high inflation driven by food and fuel prices, and has since remained appreciated though not out of line from regional peers (text chart). The goods trade balance worsened over the same period, with an increase in exports (mainly fish) more than offset by that in imports. The trend of real exchange rate, however, is expected to reverse as inflationary pressures subdue over the medium term.

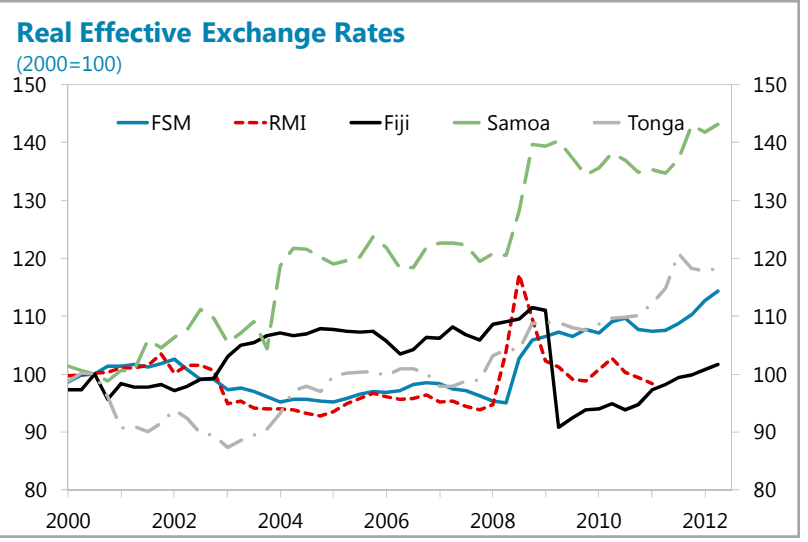

29. Despite the real appreciation, the risks to external stability are currently limited. The large current account deficit is financed through foreign assistance. Compact-related financial flows are the main determinant of external balances and will continue to provide a stable source of funding over the next decade, while external debt is expected to decline in terms of GDP. It should be kept in mind, however, that fiscal and structural reforms are essential for securing external stability after the expiry of Compact grants. The use of the U.S. dollar as the official currency is appropriate given the small size of the economy and its close financial and trade linkages with the United States.

\section{Authorities' Views}

30. The authorities broadly shared staff's assessment on the external stability and the real exchange rate. They highlighted, however, the tendency of the price level in the FSM to keep elevated even after international food and fuel prices have stabilized. They also highlighted the limited policy options available to respond to such price shocks while agreeing that use of the U.S. dollar as the domestic currency remains appropriate for the FSM given its limited administrative capacity for independent monetary and exchange rate policies.

\section{Private Sector}

31. Sustainable growth will require a vibrant private sector. The structure of the FSM economy has changed little over the last decade-the share of the public sector stands at 38 percent, the private sector at 22 percent, and the household at 31 percent. The key bottlenecks for private sector development include difficulties in obtaining secure long-term land leases, reliance on a single carrier operating high-priced flights, poor infrastructure, and lack of skilled labor. Moreover, some public enterprises crowd out precious financial and human resources from other sectors of the country, and constrain productivity growth of the entire economy through inefficient or costly services. While some key infrastructure projects are underway, the government could further support private sector growth by accelerating infrastructure investments and providing a more business-friendly environment. 
32. Reforms to attract inward FDI could have an immediate impact on activity as part of an overall development strategy. Given the FSM's competitive advantage in some niche tourism markets, a more focused approach on improving inward FDI in these areas could generate immediate benefits. In particular, addressing issues regarding obtaining longer-term land leases and burdensome procedures of approval for foreign investment would help facilitate tourism FDI. Other measures to improve business environment include: committing long-term government support for the College of the FSM in training future workers; keeping public wages in check to reduce the large public-private sector wage gap; and advancing the public enterprises reform to encourage new entrants for more competition in the provision of infrastructure services including through increasing private sector participation in public enterprises, where feasible. The FSM's first Development Partners Forum, held in early November to discuss economic and development challenges for the FSM, provided an excellent opportunity for representatives from national and local governments, private sector, civil society and international partners to sit together and explore possible paths to the future growth. It is essential to keep the momentum going and ensure the forum is followed by concrete action plans with strong engagement by stakeholders.

\section{Authorities' Views}

33. The authorities shared the staff's view that the FSM business environment remains very challenging. They cited land issue as the most difficult impediment to investment from outside, as it is so intricately connected to people's perception of inheritance and community. Also, some foreign investors do not appear to appreciate the size and culture of local economy and tend to plan unrealistically large projects, only to trigger strong oppositions and concerns from traditional communities and civil societies. Nonetheless, the authorities see potential in areas, such as fisheries, agriculture (niche tropical products) and eco-tourism, and are striving to improve transportation access to and from other Pacific countries as well as more populous countries in Asia. They stressed the importance of advancing these efforts in tandem with upgrading the core infrastructure.

\section{Financial Sector}

34. The banking sector is well capitalized and with sufficient liquidity, but renders little support to the private sector with a low loan-to-deposit ratio (33 percent at end-FY2011). While deposits are steadily increasing over the past three years, majority of them are invested by banks in safe financial assets overseas rather than being lent to the private sector, apparently due to lack of bankable projects. The introduction of the Secured Transactions Act in 2006 has facilitated taking movable property as collateral and did help banks to extend loans to those customers they would not have been able to lend to before, but it has not so far led to boosting commercial lending. Further legislative measures to facilitate taking immovable property as collateral are necessary to increase commercial lending. Increasing availability of consumer loans may have contributed to a pick-up in inflation in recent years, and while NPLs remain relatively low at just over 31/2 percent, careful monitoring of credit quality is warranted.

35. The FSM Development Bank continues to be engaged in consumer lending. While the main focus of the bank stipulated in the law is to provide loans for high priority projects, it continues to provide consumer loans in direct competition with private banks. The Development Bank should 
return to its mandate of fostering new businesses to complement private banks. Moreover, it lacks sufficient risk assessment capacity and provisioning against consumer loans. Appropriate supervision of the Development Bank, together with credit unions, in line with international best practices, is key to financial stability. The mission urged that capacity of the regulatory authorities should be enhanced to include the supervision of lending activities by the Development Bank and credit unions. In the area of insurance, strengthening the regulatory and supervisory

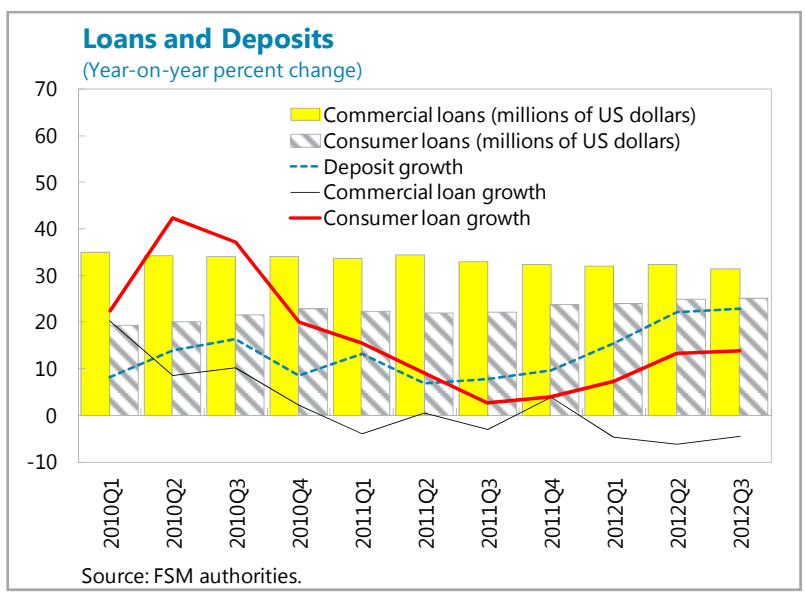
capacity is a priority in view of the increasing activities of captive insurance companies.

\section{Authorities' Views}

36. The authorities confirmed that staff's assessment of financial sector stability is consistent with their own views. In order to strengthen its supervision of the broader financial sector, the FSM banking commission is preparing a draft bill on regulation and supervision of credit unions. While they generally support placing the FSM Development Bank under appropriate supervision, they cautioned that it would call for significant political decision to realize such policy change.

\section{E. Other Issues}

37. Improving the reliability, coverage, and timeliness of economic statistics would better guide policies. Staff notes ongoing efforts by the Office of Statistics, Budget and Economic Management, Overseas Development Assistance, and Compact Management (SBOC) to improve data collection and management, including efforts to release quarterly CPI data and upgrade its website. The authorities are encouraged to further enrich statistics and use them for policy-making. In particular, it is crucial to collect and consolidate fiscal data across national and state governments in a timely manner.

\section{STAFF APPRAISAL}

38. Medium-term growth prospects in the FSM remain weak as sluggish private sector growth is insufficient to offset the scheduled decline in Compact grants. While ongoing construction projects and a further expansion of the fisheries sector will render some support to growth in the near term, risks to the outlook are on the downside. Medium-term prospects are weighed down by the reduction of Compact grants and weak private sector.

39. Risks to external stability are currently limited. The external balance is sustained by a stable flow of official transfers. It should be noted, however, that failure to address challenge of Compact grants expiry in FY2023 would cause difficulty in financing external deficit as well. The use 
of the U.S. dollar as the official currency remains appropriate given the small size of the economy and its close financial and trade linkages with the United States.

40. There is considerable risk that the CTF would not reach the necessary level for selfsufficiency. Both the national and states government should agree to realistic plans of reform and start implementing them as soon as possible. In this light, approval of the budget for establishment of the 2023 Planning Committee is urgently needed.

41. The government needs to prepare and adopt a credible fiscal strategy to deal with the looming revenue gap in FY2023. The guiding principles should be: (i) a realistic macroeconomic framework; (ii) a balanced fiscal adjustment path; (iii) policy buffers to guard against possible shocks; and, (iv) broad buy-in by the public and state governments.

42. To secure fiscal sustainability substantial fiscal reforms are needed. Passage of the planned comprehensive tax reform should be accelerated with increasing efforts of engaging state governments and the general public to garner their support. In addition to savings from improved operational efficiency of overall government expenditure, public sector wage growth should be curtailed.

43. Public sector financial management should be strengthened to complement and safeguard the benefits of fiscal reforms. Staff encourages the authorities to devise a fiscal rule requiring fiscal surpluses to be transferred to the CTF.

44. Underfunding of the social security fund poses another sustainability concern. While recognizing the recent efforts to reduce the imbalance through increasing the social security tax rates, the authorities are urged to prepare further comprehensive measures including on the system design to protect the value of the social security fund.

45. Advancing structural reforms to facilitate investment by both domestic and foreign investors is critical in order to minimize the possible growth impact from expected fiscal reforms. In addition to further liberalizing land use and lease, streamlining procedures related to investment permits both at the national and state level will help. Reforming of public enterprises should also contribute to higher productivity through better use of financial and human resources. These structural reforms should be pursued through setting a clear nation-wide development plan in line with the Development Strategy adopted in the first Development Partners Forum.

46. The financial system is stable, but should lend more support to private sector development. Though the banking sector remains well capitalized and sufficiently liquid, its credit quality warrants careful monitoring as consumer loans increase. The FSM Development Bank should be brought under appropriate supervision and redirected to help financing the viable start-ups rather than directly competing with private banks over consumer loans.

47. It recommended that the next Article IV consultation take place on the $\mathbf{2 4}$ month cycle. 


\section{Box 1. Micronesia: Fiscal Arrangements and Operational Challenges in Compact Grants Utilization ${ }^{1}$}

\section{Overview of the FSM fiscal structure.}

Most of service delivery functions (for example, health and education) are assigned to the State Governments, and they are financed through a combination of fiscal transfers from the National Government and the States' share in domestically generated revenue. Unit costing data that would allow for an assessment of the link between functional assignments and financing arrangements are not available.

The key sources of these fiscal transfers to the state governments are the Compact Sector Grants, the Compact Infrastructure Grant, the Compact Supplemental Education Grant, and grants made available through the Federal Program, all of which are made available by the United States. At the aggregate level, these grants make up for over 60 percent of total allocations; the balance is made up mainly by the FSM General Fund (comprising domestic tax and non-tax revenue). The majority of the Compact sector grants (85 percent) and the Compact Infrastructure Grant (75 percent) is earmarked for operational and investment support for the education and health sectors.

Over 90 percent of the Compact Funds are allocated to the State Governments, while the National Government receives 67 percent of the Domestic Funds and roughly half of the U.S. Federal Grants and other external assistance. The table below provides an overview of submitted budget allocations for FY2013, broken down by type of transfer or revenue sharing arrangement.

\section{Challenges in Compact grants utilization.}

There are several possible causes for delay in Compact grants utilization:

\section{a. Mismatches in budget calendar}

Information on the Compact grants available for the next fiscal year is typically conveyed to state governments 4-5 months into the current fiscal year. State legislatures typically approve the state budgets in September (end of FY), leaving little time for coordination with national and other state governments.

\section{b. Weak monitoring and management of projects}

Infrastructure projects are centrally managed at Project Management Unit of the national government, but it is often a challenge to keep most updated information about prospects, estimated costs, and progress of individual projects in all four states.

\section{c. Lack of timely data available on fiscal activities of national and state governments}

Data on fiscal activities of national and state governments in the ongoing year are not available in a timely manner, making it hard to grasp the current status of consolidated government activities. Although the financial statements of the national government are submitted for audit within 6 months from the end of fiscal year, coordination and reallocation between national and state governments during the fiscal year is very difficult.

\section{d. Coordination problems on the allocation of infrastructure grants across state governments}

As the cost of infrastructure projects in individual states, such as the building of roads or power stations are large relative to the size of the state, reaching agreement on the allocation of funds is politically difficult given the limited economic spillovers to other states due to the large geographic distance between the states.

The opportunity costs associated with delay and under-utilization of Compact grants are substantial, and overcoming these impediments could lead to significant economic and efficiency gains.

${ }^{1}$ Prepared with inputs by Hans van Rijn of Asian Development Bank. 


\begin{tabular}{|c|c|c|c|c|c|c|}
\hline \multicolumn{7}{|c|}{ Intergovernmental Fiscal Transfers and the Allocation of Domestic Revenues (US\$, FY2013) } \\
\hline & National & Chuuk & Kosrae & Pohnpei & Yap & Line Totals \\
\hline Population & & 48,654 & 6,616 & 36,196 & 11,377 & 102,843 \\
\hline \multicolumn{7}{|l|}{ I. REGULAR SECTOR ("Operations") } \\
\hline A. Education Sector & $4,353,841$ & $9,603,527$ & $2,447,446$ & $7,374,354$ & $3,880,125$ & $27,659,293$ \\
\hline B. Health Sector & 895,705 & $8,608,714$ & $2,111,506$ & $5,768,196$ & $3,308,441$ & $20,692,562$ \\
\hline C. Public Sector Capacity Building & 0 & $1,300,506$ & 502,060 & 421,057 & 506,512 & $2,730,135$ \\
\hline D. Environment Sector & 0 & 685,341 & 215,903 & 447,987 & 364,550 & $1,713,781$ \\
\hline E. Private Sector Development & 0 & 851,135 & 782,463 & 157,000 & 795,663 & $2,586,260$ \\
\hline F. Enhanced Reporting \& Accountability & 222,450 & 619,095 & 177,582 & 288,645 & 173,465 & $1,481,236$ \\
\hline Subtotal Operations & $5,471,996$ & $21,668,318$ & $6,236,959$ & $14,457,239$ & $9,028,756$ & $56,863,268$ \\
\hline II. COMPACT INFRASTRUCTURE GRANT & $2,443,795$ & $9,286,422$ & $2,663,737$ & $6,185,246$ & $3,858,752$ & $24,437,952$ \\
\hline III. SUPPLEMENTAL EDUCATION GRANT & $1,175,163$ & $4,465,620$ & $1,280,928$ & $2,974,339$ & $1,855,583$ & $11,751,634$ \\
\hline Subtotal I+II+III & $9,090,954$ & $35,420,360$ & $10,181,624$ & $23,616,824$ & $14,743,091$ & $93,052,854$ \\
\hline Share by Government (I+II+III) & 9.8 & 38.1 & 10.9 & 25.4 & 15.8 & 100.0 \\
\hline IV. US FEDERAL PROGRAM (Federal Grants) & $4,524,810$ & 682,854 & 926,259 & $1,954,974$ & $1,661,080$ & $9,749,976$ \\
\hline Share by Government & 46.4 & 7.0 & 9.5 & 20.1 & 17.0 & 100.0 \\
\hline V. GENERAL FUND (Domestic Revenue) & $43,191,184$ & $6,735,229$ & $1,974,544$ & $7,332,640$ & $5,490,187$ & $64,723,784$ \\
\hline Share by Government & 66.7 & 10.4 & 3.1 & 11.3 & 8.5 & 100.0 \\
\hline VI. OTHER EXTERNAL ASSISTANCE & 310,760 & 0 & 183,000 & 77,604 & 0 & 571,364 \\
\hline Share by Government & 54.4 & 0.0 & 32.0 & 13.6 & 0.0 & 100.0 \\
\hline Totals by National and State Government & $57,117,708$ & $42,838,443$ & $13,265,426$ & $32,982,042$ & $21,894,358$ & \\
\hline Share in aggregate budget (by Government) & 34.0 & 25.5 & 7.9 & 19.6 & 13.0 & \\
\hline GRAND TOTAL & $168,097,978$ & & & & & \\
\hline Share of US grants (I-IV) & 61.2 & & & & & \\
\hline Share of General Fund (V) & 38.5 & & & & & \\
\hline Share of Other External Assistance (VI) & 0.3 & & & & & \\
\hline Source: Data provided by the FSM authoriti & & & & & & \\
\hline
\end{tabular}




\section{Box 2. Micronesia: The Challenge of Commodity Price Volatility on Inflation}

The Federated States of Micronesia (FSM), as many other Pacific Islands countries, relies heavily on imports to support domestic consumption. The country imported goods equivalent to 60 percent of GDP in 2011, with combined share of food and fuels just slightly below half of total imports. The share of imported goods and services in FSM's CPI baskets is high at 76.3 percent, with 30.5 percent of imported food. Fuel prices account only for 3.4 percent of total basket. However, when considering electricity and transportation, for which fuel oil price adjustment is a major component in retail pricing, the impact of world oil price changes on domestic inflation is more significant.

Changes in global food and oil prices are passed through at different speeds and patterns. Based on a VAR analysis of world oil and food prices on FSM's price index, we find that changes on global commodity prices, with some lags, have direct short-term impacts on domestic inflation. Oil prices shocks are only partially passed-through with a lag of one quarter. Due to the retail pricing scheme of FSM Petroleum Corporation, a state-owned company and the only fuel importer and distributor in the country, changes in retail prices are made every four months. Domestic food prices respond to world price shocks with a lag of about two quarters, but have a stronger persistence.

During the first wave of world commodity price increases during 2005-08, domestic inflation remained relatively muted between 4-5 percent, compared to 3-4 percent in the United States, thanks to limited impact of fuel prices on inflation and switching to lower-quality imports. However, inflation rose sharply to above 10 percent starting late 2008 after a shock in world prices of rice, the main staple food in the country, before subsiding at the end of 2009. Domestic prices started to edge up again in early 2010 as world commodity prices resumed upward trend and domestic demand improved.
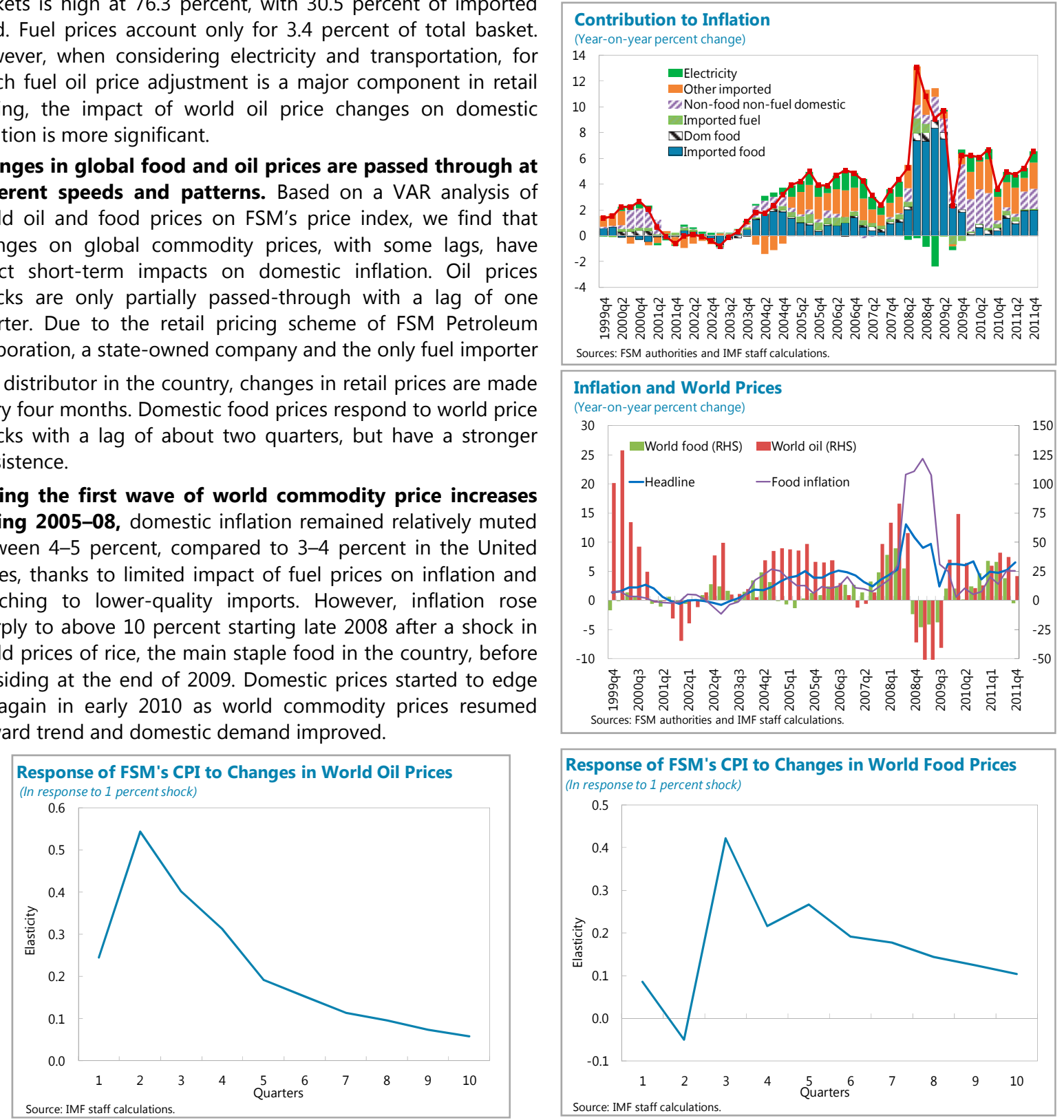

Looking forward, as the world commodity prices are expected to remain elevated and volatile, direct pass-through would potentially worsen the external positions and real incomes of the poor. ${ }^{1}$ In order to better prepare against large commodity prices shocks, long-term measures to mitigate the price volatility impacts should be considered, including promoting domestic food supply through commercial farming, redesigning utility price scheme for slower fuel price passthough while avoiding undue burden on public finance, and allowing more competition in importing businesses.

${ }^{1}$ According to a recent study by Sheridan, Tumbarello and Wu (IMF Working Paper WP/12/154 - June 2012), real oil price shocks also have a large impact on Micronesia GDP in the short term, as 10-percent increase in oil prices lowering GDP growth by 0.08 percent. 
Figure 1. Micronesia: From Crisis to Recovery—Rebuilding Policy Buffers

Micronesia's overall buffer to withstand shocks has remained weak...

Overall Buffer Index, 2004-07 and 2012 1/

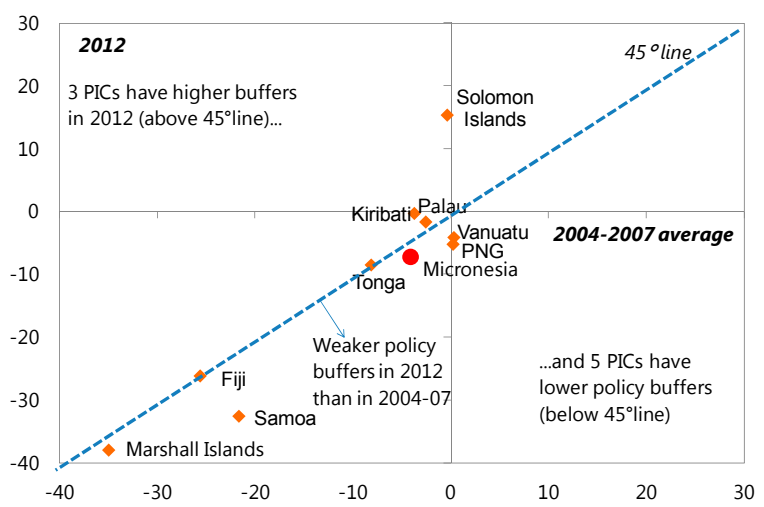

The fiscal balance in 2012 improved thanks to high fishing fees revenue...

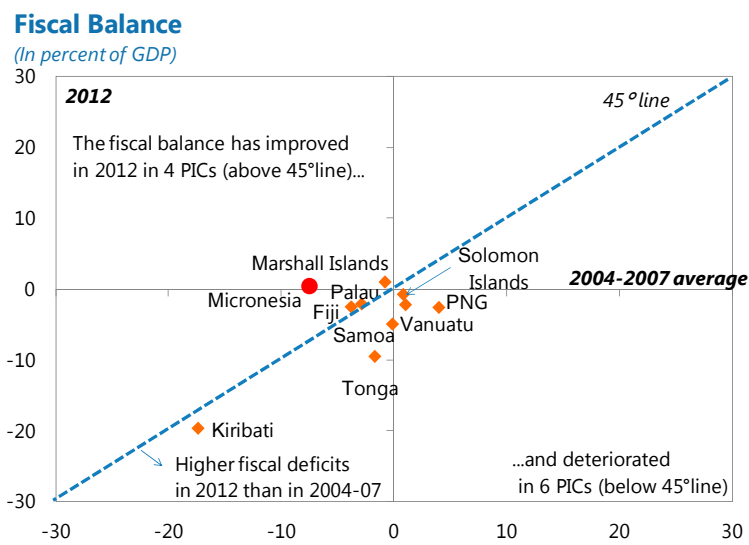

The current account position, net of FDI, deteriorated in recent years...

Current Account and FDI

$$
\text { (In percent of GDP) }
$$

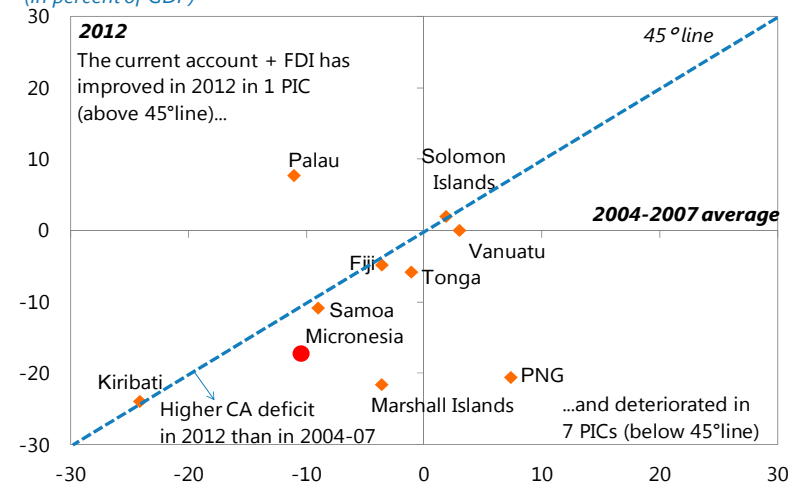

... and inflation is higher than during the pre-crisis period....

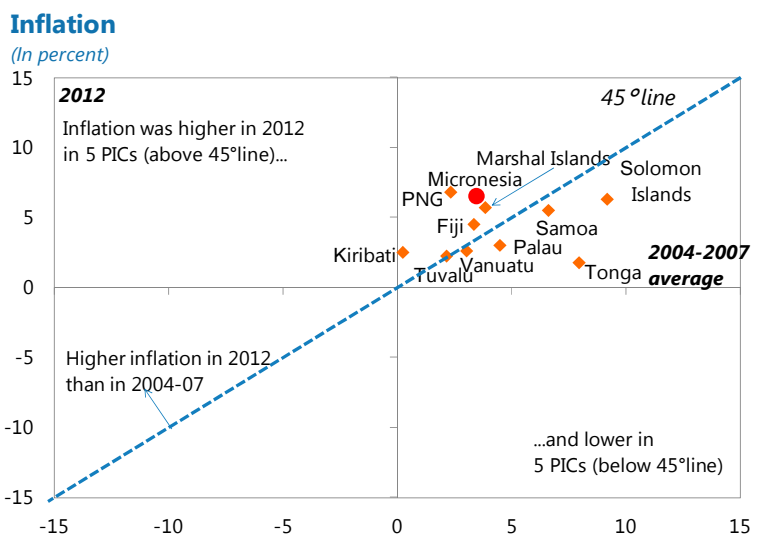

... and debt remains at a low level, though slightly above the 2004-07 average...

\section{Gross Debt}

(In percent of GDP)

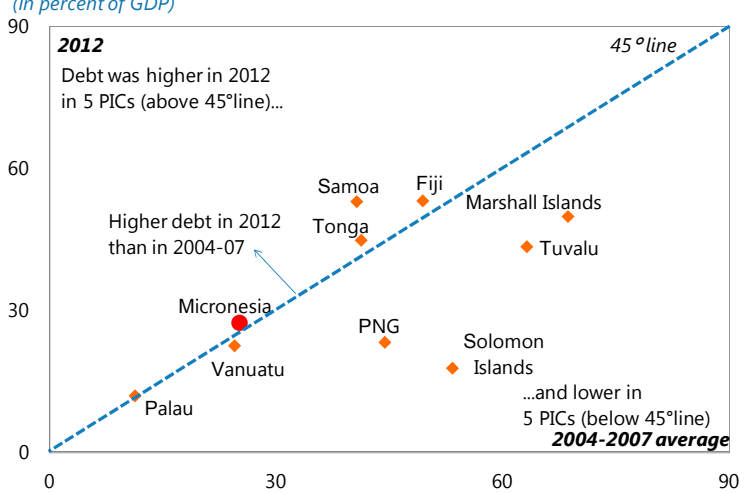

... though it is sustained by a stable flow of official transfers, and reserves have increased.

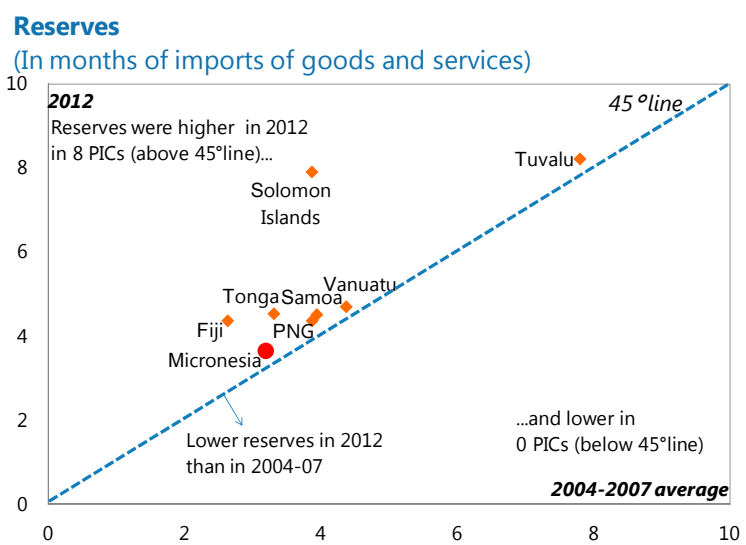

Source: Country authorities and Fund staff calculations.

$1 /$ The overall buffer index is the sum of five individual buffers normalized by their respective standard deviations during $2004-07$. 


\section{Figure 2. Micronesia: Economic Developments and Outlook}

Over a longer horizon, growth has been sluggish, with some improvements in recent years.

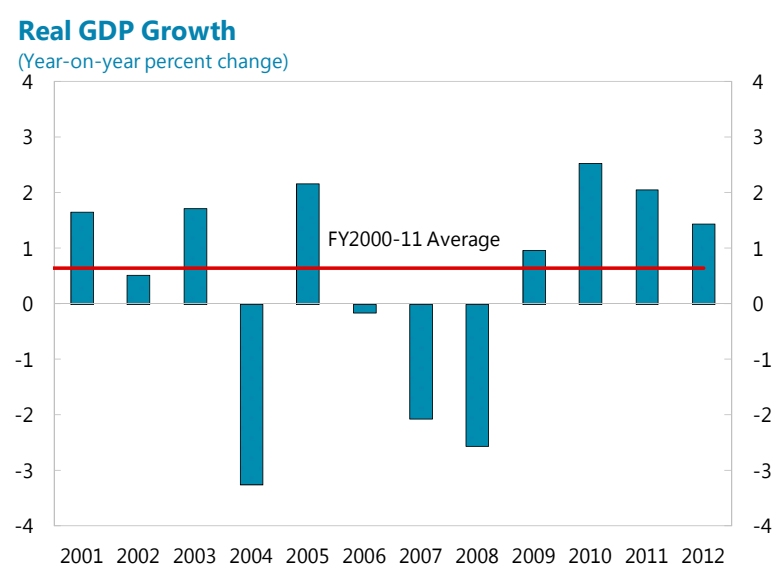

Fiscal balance has remained in surplus, though not sufficiently large.

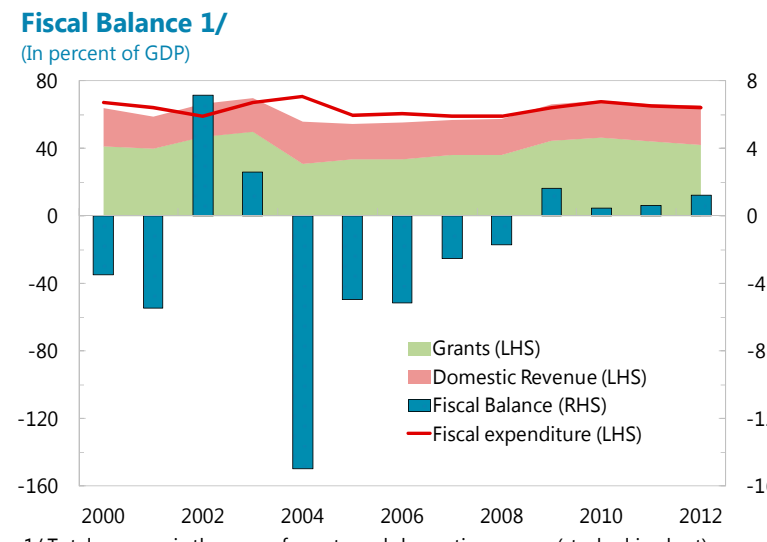

1 / Total revenue is the sum of grants and domestic revenue (stacked in chart).

The current account deficit remains sizable, but largely offset by official capital inflows.

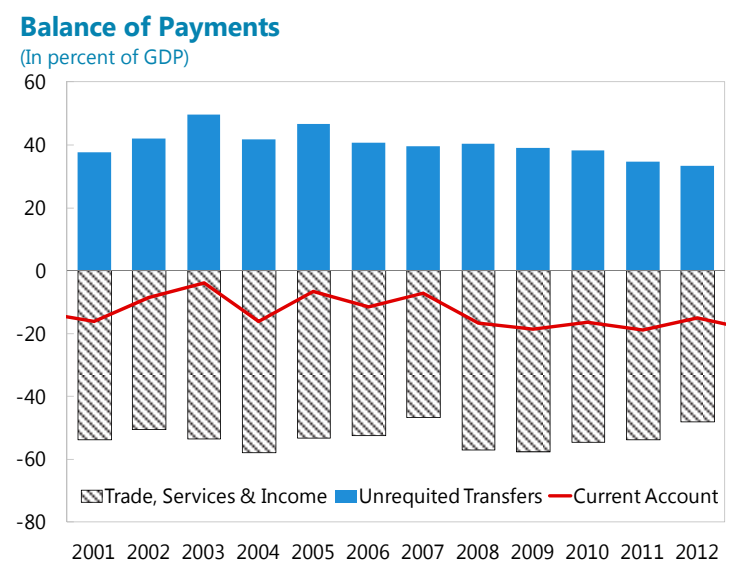

Growth has mainly been driven by the fishery sector, as well as public construction, which is not a sustainable source of growth.

Contribution to Growth

(As share to real GDP)

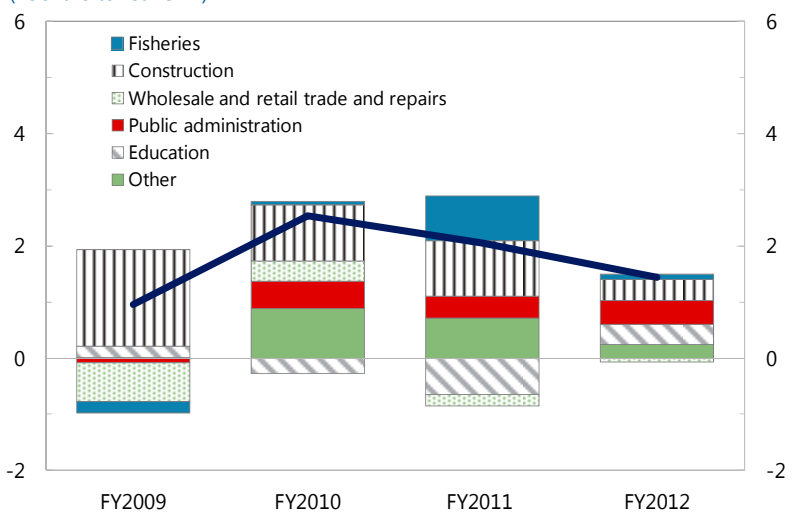

Inflation is volatile and higher than in the U.S., driven by food and commodity prices.

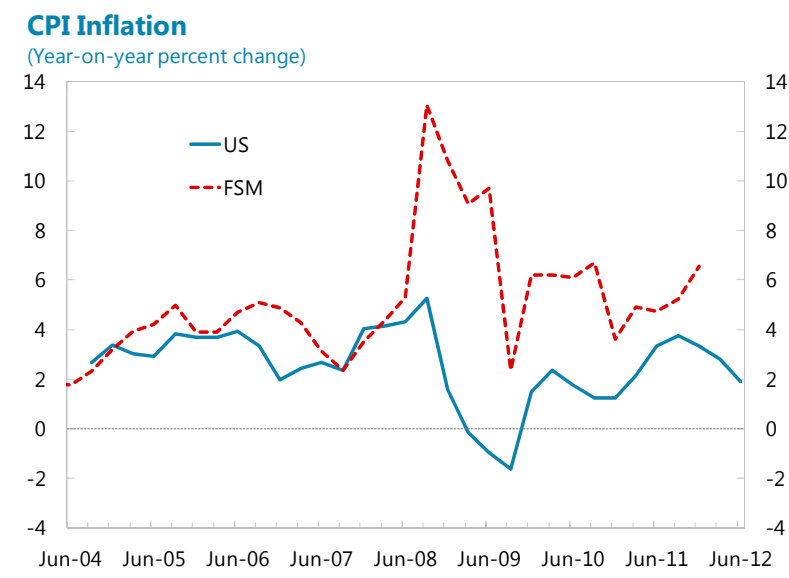

While private sector employment increased over the years, recent growth has been concentrated in a few industries, mainly fisheries and construction.
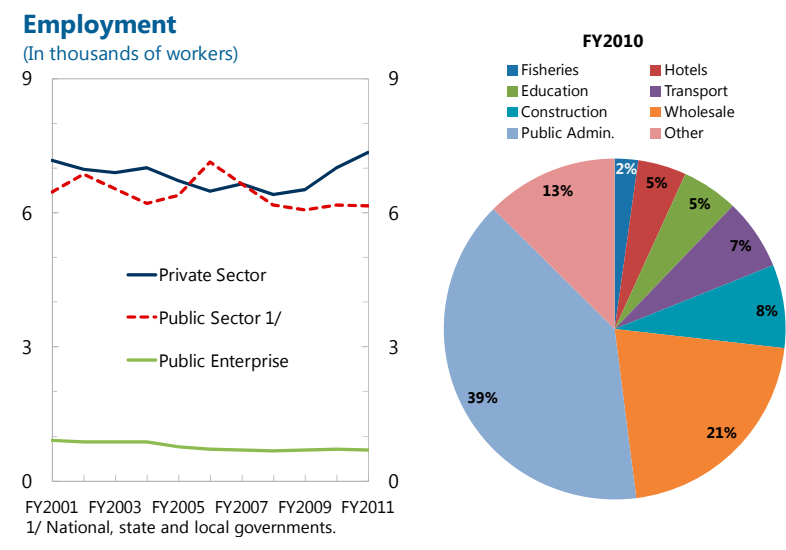


\begin{tabular}{|c|c|c|c|c|c|c|}
\hline \multicolumn{7}{|c|}{ Table 1. Micronesia: Basic Data, FY2008-13 1/ } \\
\hline $\begin{array}{ll}\text { Nominal GDP (FY2012): } & \text { US\$327 million } \\
\text { Population (FY2012): } & 102,704 \\
\text { GDP per capita (FY2012): } & \text { US\$3,185 } \\
\text { IMF Quota: } & \text { SDR5.1 million }\end{array}$ & & & & & & \\
\hline & FY2008 & FY2009 & FY2010 & FY2011 & $\begin{array}{r}\text { FY2012 } \\
\text { Est. }\end{array}$ & $\begin{array}{r}\text { FY2013 } \\
\text { Proj. }\end{array}$ \\
\hline \multicolumn{7}{|c|}{ Real sector (average annual percent change unless otherwise noted) } \\
\hline $\begin{array}{l}\text { Real GDP } \\
\text { Consumer prices }\end{array}$ & $\begin{array}{r}-2.6 \\
6.6\end{array}$ & $\begin{array}{l}1.0 \\
7.8\end{array}$ & $\begin{array}{l}2.5 \\
6.3\end{array}$ & $\begin{array}{l}2.1 \\
4.6\end{array}$ & $\begin{array}{l}1.4 \\
5.6\end{array}$ & $\begin{array}{l}0.8 \\
4.2\end{array}$ \\
\hline $\begin{array}{l}\text { Employment } \\
\text { Public (incl. public enterprises) } \\
\text { Private }\end{array}$ & $\begin{array}{l}-4.8 \\
-6.3 \\
-3.5\end{array}$ & $\begin{array}{r}-0.3 \\
-2.1 \\
1.7\end{array}$ & $\begin{array}{l}4.1 \\
1.3 \\
7.4\end{array}$ & $\begin{array}{r}2.3 \\
-0.2 \\
5.0\end{array}$ & $\begin{array}{l}0.2 \\
0.1 \\
0.3\end{array}$ & $\begin{array}{l}0.1 \\
0.1 \\
0.2\end{array}$ \\
\hline $\begin{array}{l}\text { Nominal wages } \\
\text { Public-private wage ratio }\end{array}$ & $\begin{array}{l}3.7 \\
2.1\end{array}$ & $\begin{array}{l}4.2 \\
2.2\end{array}$ & $\begin{array}{l}2.5 \\
2.2\end{array}$ & $\begin{array}{l}0.1 \\
2.1\end{array}$ & $\begin{array}{l}2.7 \\
2.1\end{array}$ & $\begin{array}{l}2.7 \\
2.1\end{array}$ \\
\hline \multicolumn{7}{|c|}{ Consolidated government finance (in percent of GDP) } \\
\hline $\begin{array}{l}\text { Revenue and grants } \\
\text { Revenue } \\
\text { Grants } \\
\text { Expenditure } \\
\text { Current } \\
\text { Capital } \\
\text { Overall balance }\end{array}$ & $\begin{array}{r}57.3 \\
21.2 \\
36.1 \\
59.0 \\
50.2 \\
8.8 \\
-1.7\end{array}$ & $\begin{array}{r}65.9 \\
21.4 \\
44.5 \\
64.2 \\
47.4 \\
16.9 \\
1.6\end{array}$ & $\begin{array}{r}68.2 \\
21.8 \\
46.3 \\
67.7 \\
48.1 \\
19.6 \\
0.5\end{array}$ & $\begin{array}{r}65.9 \\
21.8 \\
44.1 \\
65.3 \\
46.9 \\
18.4 \\
0.6\end{array}$ & $\begin{array}{r}65.2 \\
23.3 \\
42.0 \\
64.0 \\
46.8 \\
17.2 \\
1.2\end{array}$ & $\begin{array}{r}62.6 \\
22.0 \\
40.6 \\
61.8 \\
45.3 \\
16.6 \\
0.8\end{array}$ \\
\hline Compact Trust Fund (millions of U.S. dollars) & 119.1 & 138.3 & 177.2 & 198.5 & 257.4 & 297.5 \\
\hline \multicolumn{7}{|c|}{ Commercial banks (in millions of U.S. dollars; end of period) } \\
\hline $\begin{array}{l}\text { Foreign assets } \\
\text { Loans } \\
\text { Total deposits }\end{array}$ & $\begin{array}{r}101.4 \\
49.2 \\
118.9\end{array}$ & $\begin{array}{r}121.5 \\
46.7 \\
132.5\end{array}$ & $\begin{array}{r}127.7 \\
55.7 \\
154.1\end{array}$ & $\begin{array}{r}143.6 \\
55.2 \\
166.2\end{array}$ & $\begin{array}{r}156.2 \\
60.0 \\
175.2\end{array}$ & $\begin{array}{r}169.8 \\
65.3 \\
181.8\end{array}$ \\
\hline $\begin{array}{l}\text { Interest rates (in percent, average for FY) } \\
\text { Consumer loans } \\
\text { Commercial loans }\end{array}$ & $\begin{array}{r}14.4 \\
8.5\end{array}$ & $\begin{array}{r}15.4 \\
7.4\end{array}$ & $\begin{array}{r}15.1 \\
6.6\end{array}$ & $\begin{array}{r}14.4 \\
6.6\end{array}$ & $\begin{array}{r}15.0 \\
8.1\end{array}$ & $\begin{array}{r}14.8 \\
7.7\end{array}$ \\
\hline $\begin{array}{l}\text { Balance of payments (in millions of U.S. dolla } \\
\text { Trade balance } \\
\text { Net services and income } \\
\text { Private and official transfers } \\
\text { Current account including official transfers } \\
\text { (in percent of GDP) } \\
\text { Current account excluding official transfers } \\
\text { (in percent of GDP) }\end{array}$ & $\begin{array}{r}-121.7 \\
-27.6 \\
105.5 \\
-43.8 \\
-16.7 \\
-142.6 \\
-54.6\end{array}$ & $\begin{array}{r}-128.4 \\
-31.3 \\
108.4 \\
-51.3 \\
-18.5 \\
-155.9 \\
-56.2\end{array}$ & $\begin{array}{r}-130.7 \\
-30.1 \\
112.1 \\
-48.7 \\
-16.6 \\
-157.2 \\
-53.4\end{array}$ & $\begin{array}{r}-134.2 \\
-32.4 \\
108.0 \\
-58.6 \\
-18.9 \\
-162.2 \\
-52.3\end{array}$ & $\begin{array}{r}-133.1 \\
-24.5 \\
108.7 \\
-49.0 \\
-15.0 \\
-153.9 \\
-47.0\end{array}$ & $\begin{array}{r}-130.4 \\
-25.6 \\
107.3 \\
-48.7 \\
-14.3 \\
-152.0 \\
-44.8\end{array}$ \\
\hline $\begin{array}{l}\text { Overall balance } \\
\text { (in percent of GDP) }\end{array}$ & $\begin{array}{l}-3.0 \\
-1.2\end{array}$ & $\begin{array}{l}-1.6 \\
-0.6\end{array}$ & $\begin{array}{l}-0.3 \\
-0.1\end{array}$ & $\begin{array}{l}0.9 \\
0.3\end{array}$ & $\begin{array}{l}6.5 \\
2.0\end{array}$ & $\begin{array}{l}0.9 \\
0.3\end{array}$ \\
\hline Gross reserves (in months of imports) & 2.5 & 2.7 & 2.8 & 3.6 & 3.6 & 3.6 \\
\hline $\begin{array}{l}\text { External debt (in millions of U.S. dollars; end } \\
\text { Stock } \\
\quad \text { (in percent of GDP) } \\
\text { Debt service } \\
\quad \text { (in percent of exports of goods and services) }\end{array}$ & $\begin{array}{c}\text { of period) } \\
74.1 \\
28.4 \\
3.2 \\
5.4\end{array}$ & $\begin{array}{r}84.6 \\
30.5 \\
3.9 \\
6.6\end{array}$ & $\begin{array}{r}84.3 \\
28.7 \\
4.3 \\
6.6\end{array}$ & $\begin{array}{r}87.1 \\
28.1 \\
5.0 \\
6.9\end{array}$ & $\begin{array}{r}87.1 \\
26.6 \\
5.1 \\
6.6\end{array}$ & $\begin{array}{r}87.1 \\
25.7 \\
5.0 \\
6.1\end{array}$ \\
\hline $\begin{array}{l}\text { Exchange rate regime } \\
\text { Real effective exchange rate } 3 /\end{array}$ & $\begin{array}{l}\text { U.S. dollar } \\
\quad 97.5\end{array}$ & $\begin{array}{c}\text { is the offic } \\
106.7\end{array}$ & $\begin{array}{l}\text { ial currency } \\
108.6\end{array}$ & 107.6 & 108.1 & 108.5 \\
\hline \multicolumn{7}{|c|}{$\begin{array}{l}\text { Sources: Data provided by the FSM authorities and Fund staff estimates. } \\
\text { 1/ Fiscal year ending September 30. Estimates for FY2012 and projections for FY2013 are preliminary and based on } \\
\text { data received from the authorities. } \\
\text { 2/ Government and public enterprise debt only. } \\
\text { 3/ Year } 2000=100 \text {. }\end{array}$} \\
\hline
\end{tabular}


Table 2. Micronesia: General Government Operations, FY2008-13 1/

\begin{tabular}{|c|c|c|c|c|c|c|}
\hline & FY2008 & FY2009 & FY2010 & FY2011 & $\begin{array}{c}\text { FY2012 } \\
\text { Est. }\end{array}$ & $\begin{array}{c}\text { FY2013 } \\
\text { Proj }\end{array}$ \\
\hline & \multicolumn{6}{|c|}{ (In millions of U.S. dollars) } \\
\hline Revenue & 149.8 & 182.8 & 200.5 & 204.5 & 213.4 & 212.4 \\
\hline Tax revenue & 29.3 & 31.7 & 35.3 & 37.2 & 37.3 & 38.0 \\
\hline Wage and salary tax & 7.3 & 7.1 & 7.6 & 7.6 & 8.3 & 8.9 \\
\hline Gross revenue tax & 6.4 & 7.8 & 8.9 & 9.1 & 9.6 & 9.8 \\
\hline Import taxes & 8.4 & 9.2 & 10.1 & 9.8 & 8.1 & 8.0 \\
\hline Other taxes & 0.0 & 0.0 & 0.0 & 0.0 & 0.3 & 0.0 \\
\hline Grants (from abroad) & 94.3 & 123.5 & 136.2 & 136.8 & 137.3 & 137.8 \\
\hline Current & 79.0 & 84.4 & 85.6 & 84.0 & 85.3 & 85.6 \\
\hline Capital & 15.4 & 39.1 & 50.7 & 52.8 & 52.1 & 52.1 \\
\hline Non-tax revenue & 26.1 & 27.6 & 28.9 & 30.5 & 38.8 & 36.6 \\
\hline Fishing access revenue & 17.0 & 20.0 & 17.7 & 18.8 & 26.4 & 24.7 \\
\hline Dividend and interest income & 0.5 & 0.7 & 0.7 & 3.6 & 3.6 & 3.6 \\
\hline Other nontax revenues & 8.6 & 6.8 & 10.5 & 8.0 & 8.8 & 8.3 \\
\hline Expenditure & 154.2 & 178.2 & 199.1 & 202.5 & 209.4 & 209.7 \\
\hline Expense & 131.1 & 131.4 & 143.0 & 145.6 & 153.2 & 153.6 \\
\hline Goods and services & 127.5 & 128.9 & 139.1 & 143.5 & 151.2 & 151.4 \\
\hline Wages and salaries & 60.2 & 63.1 & 66.4 & 65.9 & 68.4 & 69.0 \\
\hline Travel & 8.2 & 8.3 & 10.0 & 9.7 & 9.7 & 9.7 \\
\hline Other & 59.1 & 57.5 & 62.7 & 67.9 & 73.1 & 72.7 \\
\hline Interest payments & 0.0 & 0.1 & 0.1 & 0.2 & 0.2 & 0.2 \\
\hline Subsidies & 2.9 & 2.3 & 2.5 & 1.9 & 1.9 & 1.9 \\
\hline Net transfers & 0.7 & 0.0 & -0.3 & 0.0 & 0.0 & 0.1 \\
\hline Capital transfers & 0.0 & 0.0 & 1.6 & 0.1 & 0.0 & 0.0 \\
\hline Net acquisition of nonfinancial assets & 23.1 & 46.8 & 56.1 & 56.9 & 56.2 & 56.2 \\
\hline Acquisition of fixed capital & 14.7 & 38.0 & 40.0 & 38.2 & 37.7 & 37.7 \\
\hline Multi-purpose development projects & 8.4 & 8.8 & 16.0 & 18.7 & 18.5 & 18.5 \\
\hline Gross operating balance & 18.6 & 51.4 & 57.4 & 58.9 & 60.2 & 58.8 \\
\hline \multirow[t]{2}{*}{ Net lending/borrowing } & -4.5 & 4.6 & 1.4 & 1.9 & 4.1 & 2.6 \\
\hline & \multicolumn{6}{|c|}{ (In percent of GDP) } \\
\hline Revenue & 57.3 & 65.9 & 68.2 & 65.9 & 65.2 & 62.6 \\
\hline Tax revenue & 11.2 & 11.4 & 12.0 & 12.0 & 11.4 & 11.2 \\
\hline Grants (from abroad) & 36.1 & 44.5 & 46.3 & 44.1 & 42.0 & 40.6 \\
\hline Non-tax revenue & 10.0 & 9.9 & 9.8 & 9.8 & 11.9 & 10.8 \\
\hline Expenditure & 59.0 & 64.2 & 67.7 & 65.3 & 64.0 & 61.8 \\
\hline Expense & 50.2 & 47.4 & 48.6 & 46.9 & 46.8 & 45.3 \\
\hline Net acquisition of nonfinancial assets & 8.8 & 16.9 & 19.1 & 18.4 & 17.2 & 16.6 \\
\hline Gross operating balance & 7.1 & 18.5 & 19.5 & 19.0 & 18.4 & 17.3 \\
\hline Net lending/borrowing & -1.7 & 1.6 & 0.5 & 0.6 & 1.2 & 0.8 \\
\hline \multicolumn{7}{|l|}{ Memorandum items: } \\
\hline GDP in nominal prices & 261.3 & 277.5 & 294.1 & 310.3 & 327.2 & 339.3 \\
\hline
\end{tabular}

Sources: Data provided by the FSM authorities and staff estimates.

1/ Fiscal year ending September. The consolidated fiscal accounts cover the national and four state governments. 
Table 3. Micronesia: Indicators of Financial and External Vulnerability, FY2006-12

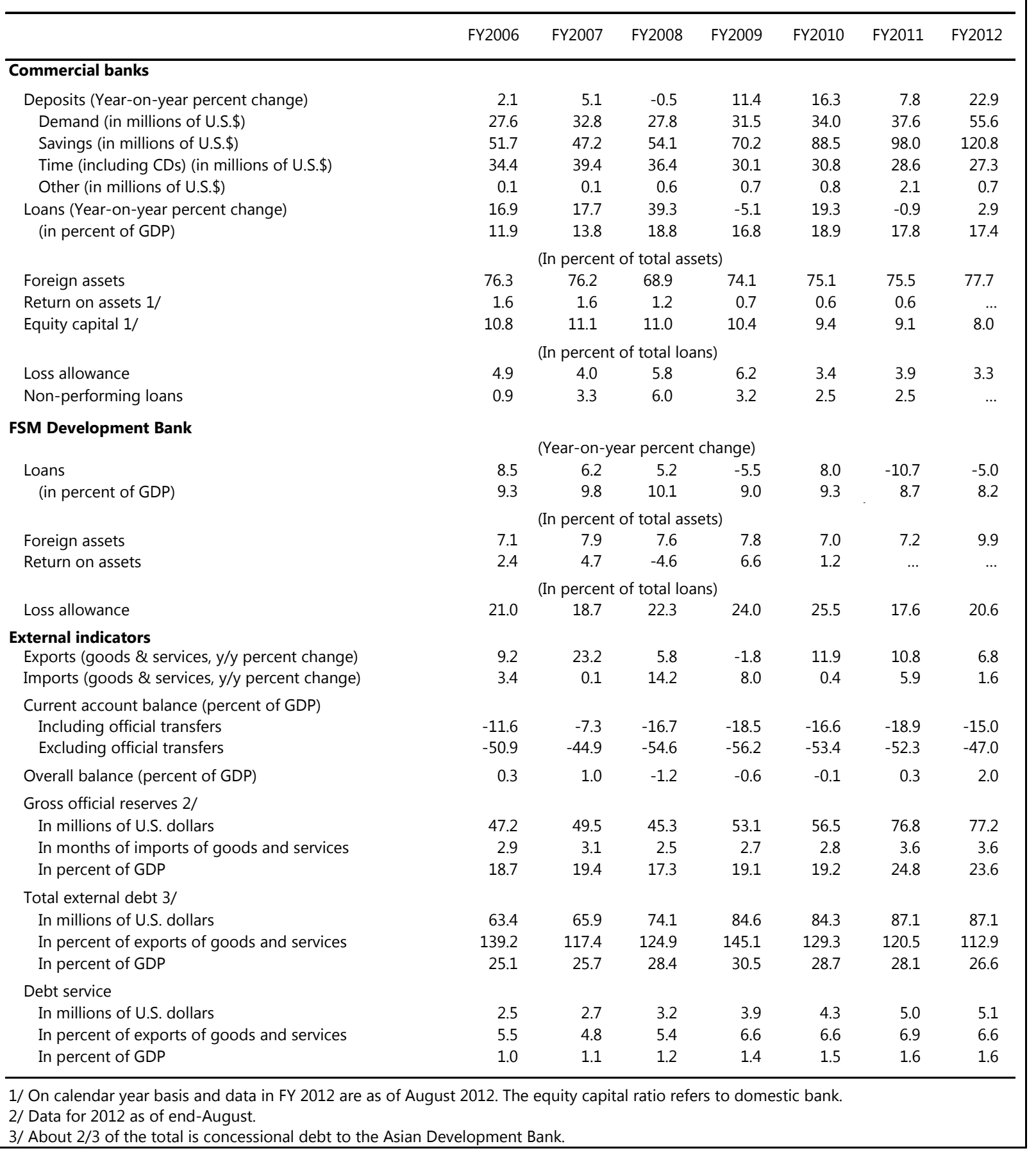




\begin{tabular}{|c|c|c|c|c|c|c|}
\hline & FY2008 & FY2009 & FY2010 & FY2011 & $\begin{array}{c}\text { FY2012 } \\
\text { Est. }\end{array}$ & $\begin{array}{l}\text { FY2013 } \\
\text { Proj. }\end{array}$ \\
\hline & \multicolumn{6}{|c|}{ (In millions of U.S. dollars) } \\
\hline Overall balance & -3.0 & -1.6 & -0.3 & 0.9 & 6.5 & 0.9 \\
\hline Current Account Balance & -43.8 & -51.3 & -48.7 & -58.6 & -49.0 & -48.7 \\
\hline Trade balance & -121.7 & -128.4 & -130.7 & -134.2 & -133.1 & -130.4 \\
\hline Exports, f.o.b. & 27.4 & 25.0 & 29.3 & 40.4 & 43.2 & 47.0 \\
\hline Imports, f.o.b. & -149.1 & -153.4 & -160.0 & -174.6 & -176.4 & -177.4 \\
\hline Petroleum products & -34.3 & -40.6 & -39.2 & -45.7 & -46.4 & -46.7 \\
\hline Services account & -39.8 & -51.9 & -43.6 & -47.4 & -47.6 & -47.6 \\
\hline Receipts & 32.0 & 33.3 & 36.0 & 31.9 & 33.9 & 35.5 \\
\hline Travel & 26.5 & 27.1 & 29.3 & 26.1 & 27.9 & 29.3 \\
\hline Communications (net) & 1.8 & 1.8 & 1.7 & 1.6 & 1.7 & 1.7 \\
\hline Other & 3.7 & 4.4 & 5.0 & 4.2 & 4.3 & 4.5 \\
\hline Payments & -71.8 & -85.2 & -79.6 & -79.2 & -81.5 & -83.0 \\
\hline Freight and insurance & -23.6 & -25.5 & -25.6 & -28.4 & -30.0 & -31.1 \\
\hline Transportation & -15.4 & -15.7 & -15.6 & -15.4 & -15.6 & -15.7 \\
\hline Travel & -7.1 & -7.5 & -8.0 & -8.3 & -8.8 & -9.1 \\
\hline Other & -25.7 & -36.5 & -30.4 & -27.1 & -27.1 & -27.1 \\
\hline Income, net & 12.2 & 20.6 & 13.6 & 14.9 & 23.0 & 22.0 \\
\hline Receipts & 27.7 & 30.7 & 26.4 & 28.1 & 35.9 & 34.7 \\
\hline Fishing rights fees & 17.0 & 20.4 & 17.6 & 19.1 & 26.4 & 24.7 \\
\hline Interest dividend income & 10.7 & 10.3 & 8.8 & 8.9 & 9.5 & 10.0 \\
\hline Payments & -15.5 & -10.2 & -12.8 & -13.1 & -12.8 & -12.7 \\
\hline Foreign workers earnings & -1.6 & -2.2 & -2.6 & -2.7 & -2.7 & -2.7 \\
\hline Interest payments & -1.8 & -2.1 & -2.4 & -2.4 & -2.1 & -2.0 \\
\hline Dividends & -12.1 & -5.9 & -7.7 & -8.0 & -8.0 & -8.0 \\
\hline Unrequited transfers & 105.5 & 108.4 & 112.1 & 108.0 & 108.7 & 107.3 \\
\hline Private & 6.7 & 3.8 & 3.6 & 4.4 & 3.8 & 4.0 \\
\hline Inflows & 17.4 & 18.2 & 18.9 & 20.1 & 19.5 & 19.8 \\
\hline Outflows & -10.7 & -14.4 & -15.3 & -15.7 & -15.7 & -15.8 \\
\hline Official & 98.8 & 104.6 & 108.5 & 103.6 & 104.9 & 103.3 \\
\hline Compact funds & 57.9 & 65.8 & 65.9 & 66.7 & 68.0 & 68.3 \\
\hline Other & 40.9 & 38.8 & 42.6 & 36.9 & 36.9 & 34.9 \\
\hline Capital and financial account & 40.7 & 49.7 & 48.4 & 59.5 & 55.5 & 49.6 \\
\hline Capital Account Balance & 48.9 & 75.8 & 85.7 & 84.4 & 75.4 & 76.6 \\
\hline Capital Transfers, Official & 4.9 & 7.5 & 16.3 & 19.2 & 24.2 & 24.4 \\
\hline Trust Fund Grants & 19.0 & 20.9 & 21.5 & 22.4 & 23.3 & 24.5 \\
\hline Other & 25.1 & 47.4 & 47.9 & 42.7 & 27.9 & 27.7 \\
\hline Financial Account Balance & -8.2 & -26.1 & -37.4 & -24.9 & -19.8 & -27.0 \\
\hline Direct Investment (net) & -5.3 & 0.6 & 0.8 & 0.8 & 0.8 & 0.9 \\
\hline Portfolio investment & -20.0 & -19.8 & -25.9 & -16.5 & -11.3 & -18.5 \\
\hline of which: Contributions to the Trust Fund & -19.0 & -20.9 & -21.5 & -22.4 & -23.3 & -24.5 \\
\hline Other investment (net) & 17.1 & -6.9 & -12.2 & -9.1 & -9.4 & -9.4 \\
\hline Memorandum items & \multicolumn{6}{|c|}{ (In percent of GDP) } \\
\hline Current account balance & -16.7 & -18.5 & -16.6 & -18.9 & -15.0 & -14.3 \\
\hline Trade balance & -46.6 & -46.3 & -44.5 & -43.3 & -40.7 & -38.4 \\
\hline Exports & 10.5 & 9.0 & 10.0 & 13.0 & 13.2 & 13.9 \\
\hline Imports & -57.0 & -55.3 & -54.4 & -56.3 & -53.9 & -52.3 \\
\hline Service & -15.2 & -18.7 & -14.8 & -15.3 & -14.5 & -14.0 \\
\hline Income & 4.7 & 7.4 & 4.6 & 4.8 & 7.0 & 6.5 \\
\hline Transfers & 40.4 & 39.1 & 38.1 & 34.8 & 33.2 & 31.6 \\
\hline Private & 2.6 & 1.4 & 1.2 & 1.4 & 1.2 & 1.2 \\
\hline Official & 37.8 & 37.7 & 36.9 & 33.4 & 32.1 & 30.4 \\
\hline Current account, ex. transfers & -57.1 & -57.6 & -54.7 & -53.7 & -48.2 & -46.0 \\
\hline Overall balance & -1.2 & -0.6 & -0.1 & 0.3 & 2.0 & 0.3 \\
\hline
\end{tabular}


Table 5. Micronesia: Medium-term Scenario (Current Policies), FY2009-17 1/

\begin{tabular}{|c|c|c|c|c|c|c|c|c|c|}
\hline & FY2009 & FY2010 & FY2011 & $\begin{array}{c}\text { FY2012 } \\
\text { Est. }\end{array}$ & $\begin{array}{c}\text { FY2013 } \\
\text { Proj. }\end{array}$ & $\begin{array}{c}\text { FY2014 } \\
\text { Proj. }\end{array}$ & $\begin{array}{l}\text { FY2015 } \\
\text { Proj. }\end{array}$ & $\begin{array}{l}\text { FY2016 } \\
\text { Proj. }\end{array}$ & $\begin{array}{l}\text { FY2017 } \\
\text { Proj. }\end{array}$ \\
\hline \multicolumn{10}{|l|}{ Real sector } \\
\hline Real GDP (percent change) & 1.0 & 2.5 & 2.1 & 1.4 & 0.8 & 0.7 & 0.6 & 0.6 & 0.6 \\
\hline Consumer prices (percent change) & 7.8 & 6.3 & 4.6 & 5.6 & 4.2 & 3.5 & 2.7 & 2.0 & 2.0 \\
\hline \multicolumn{10}{|l|}{ General government finance (in percent of GDP) } \\
\hline Revenue and grants & 65.9 & 68.2 & 65.9 & 65.2 & 62.6 & 60.5 & 59.3 & 58.3 & 57.5 \\
\hline Total domestic revenue & 21.4 & 21.8 & 21.8 & 23.3 & 22.0 & 21.1 & 20.8 & 20.5 & 20.2 \\
\hline Grants & 44.5 & 46.3 & 44.1 & 42.0 & 40.6 & 39.4 & 38.5 & 37.8 & 37.2 \\
\hline Expenditure & 64.2 & 67.7 & 65.3 & 64.0 & 61.8 & 59.9 & 58.6 & 57.7 & 56.9 \\
\hline Current & 47.4 & 48.1 & 46.9 & 46.8 & 45.3 & 43.9 & 43.0 & 42.4 & 41.9 \\
\hline Capital & 16.9 & 19.6 & 18.4 & 17.2 & 16.6 & 16.0 & 15.6 & 15.3 & 15.0 \\
\hline Overall balance & 1.6 & 0.5 & 0.6 & 1.2 & 0.8 & 0.6 & 0.6 & 0.6 & 0.6 \\
\hline \multicolumn{10}{|l|}{ Compact Trust Fund } \\
\hline \multicolumn{10}{|l|}{ Balance of payments (in millions of U.S. dollars) } \\
\hline Trade balance & -128.4 & -130.7 & -134.2 & -133.1 & -130.4 & -128.8 & -126.1 & -124.2 & -125.8 \\
\hline Net services & -51.9 & -43.6 & -47.4 & -47.6 & -47.6 & -47.7 & -47.9 & -48.0 & -48.1 \\
\hline Net income & 20.6 & 13.6 & 14.9 & 23.0 & 22.0 & 21.2 & 22.1 & 22.9 & 23.7 \\
\hline Private and official transfers & 108.4 & 112.1 & 108.0 & 108.7 & 107.3 & 106.3 & 104.1 & 102.4 & 100.9 \\
\hline Current account & -51.3 & -48.7 & -58.6 & -49.0 & -48.7 & -49.0 & -47.8 & -46.9 & -49.2 \\
\hline (In percent of GDP) & -18.5 & -16.6 & -18.9 & -15.0 & -14.3 & -14.0 & -13.3 & -12.8 & -13.2 \\
\hline Current account excluding official transfers & -155.9 & -157.2 & -162.2 & -153.9 & -152.0 & -151.5 & -148.0 & -145.5 & -146.4 \\
\hline (In percent of GDP) & -56.2 & -53.4 & -52.3 & -47.0 & -44.8 & -43.3 & -41.3 & -39.8 & -39.2 \\
\hline \multicolumn{10}{|l|}{ External debt (in millions of US\$; end of period) $2 /$} \\
\hline Stock & 84.6 & 84.3 & 87.1 & 87.1 & 87.1 & 86.9 & 86.8 & 86.7 & 86.3 \\
\hline (in percent of GDP) & 30.5 & 28.7 & 28.1 & 26.6 & 25.7 & 24.9 & 24.2 & 23.7 & 23.1 \\
\hline Debt service & 3.9 & 4.3 & 5.0 & 5.1 & 5.0 & 5.1 & 5.0 & 5.0 & 5.1 \\
\hline (in percent of exports of goods and services) & 6.6 & 6.6 & 6.9 & 6.6 & 6.1 & 6.0 & 5.6 & 5.2 & 5.2 \\
\hline
\end{tabular}


Table 6. Micronesia: Social Indicators 1/

\begin{tabular}{|c|c|c|c|}
\hline & \multirow[b]{2}{*}{ Micronesia } & \multicolumn{2}{|c|}{$\begin{array}{c}\text { Comparator Region/ } \\
\text { Income Group }\end{array}$} \\
\hline & & $\begin{array}{l}\text { East Asia } \\
\text { and Pacific }\end{array}$ & $\begin{array}{l}\text { Lower-middle } \\
\text { Income }\end{array}$ \\
\hline \multicolumn{4}{|l|}{ Population 1/ } \\
\hline Total population (millions) & 0.11 & 1,974 & 2,533 \\
\hline Growth rate (percent annual) & 0.4 & 0.7 & 1.6 \\
\hline Urban population (percent of population) 2/ & n.a. & 45.1 & 38.8 \\
\hline Total fertility rate (births per woman) 2/ & 3.5 & 1.8 & 2.9 \\
\hline GNI per capita (in U.S. dollars) 1/ & 2,900 & 4,235 & 1,760 \\
\hline \multicolumn{4}{|l|}{ Current public expenditure 2/ } \\
\hline Health (in percent of GDP) & 12.5 & 2.2 & 1.7 \\
\hline Education (in percent of GDP) & 6.7 & 3.8 & 4.0 \\
\hline \multicolumn{4}{|l|}{ Gross primary enrollment 2/ } \\
\hline (in percent of school age population) & 110 & 110 & 104 \\
\hline Male & 109 & 110 & 106 \\
\hline Female & 111 & 111 & 102 \\
\hline \multicolumn{4}{|l|}{ Immunization rate (percent $12-23$ months) $2 /$} \\
\hline Measles & 86 & 94 & 78 \\
\hline Diphtheria/Pertussis/Tetanus (DPT) & 91 & 94 & 77 \\
\hline \multicolumn{4}{|l|}{ Life expectancy at birth (years) 2/ } \\
\hline Total & 69 & 72 & 65 \\
\hline Male & 68 & 70 & 64 \\
\hline Female & 69 & 74 & 67 \\
\hline \multicolumn{4}{|l|}{ Mortality 2/ } \\
\hline Infant (per thousand live births) & 35 & 21 & 51 \\
\hline Under 5 (per thousand live births) & 43 & 26 & 70 \\
\hline
\end{tabular}




\section{APPENDIX I. MICRONESIA-RISK ASSESSMENT MATRIX $^{1 /}$}

\begin{tabular}{|c|c|c|}
\hline Sources of Risks & Likelihood & Potential Impact \\
\hline $\begin{array}{l}\text { Strong Intensification of the } \\
\text { Euro area crisis }\end{array}$ & $\begin{array}{l}\text { Medium } \\
\text { Further slowdown in the Euro } \\
\text { area and its negative spillover to } \\
\text { the rest of the world would lower } \\
\text { the demand for exports from the } \\
\text { FSM. }\end{array}$ & $\begin{array}{l}\text { Medium } \\
\text { Global slowdown would reduce fish exports ( } 9 \\
\text { percent of GDP) and fishing license fees (6 percent of } \\
\text { GDP). Tourism (8 percent of GDP) and household } \\
\text { remittances (6 percent of GDP) would be also } \\
\text { adversely affected. On the other hand, the adverse } \\
\text { impact would be somewhat mitigated by the FSM's } \\
\text { proximity to the growing Asia and Pacific economies } \\
\text { and its limited direct exposure to the Euro area. }\end{array}$ \\
\hline Global food price shock & $\begin{array}{l}\text { Low } \\
\text { High global food prices would } \\
\text { create inflationary pressure in the } \\
\text { FSM. }\end{array}$ & $\begin{array}{l}\text { High } \\
\text { The impact of a hike in global food prices could be } \\
\text { significant, especially for the vulnerable population, } \\
\text { as the weight of food in the FSM CPI basket is as high } \\
\text { as } 37 \text { percent. }\end{array}$ \\
\hline Global oil price shock & $\begin{array}{l}\text { Low } \\
\text { Continued turmoil in the Middle } \\
\text { East could disrupt world oil } \\
\text { supplies and increase global fuel } \\
\text { prices. }\end{array}$ & $\begin{array}{l}\text { Medium } \\
\text { Although the weight of fuel in the CPI basket ( } 9 \\
\text { percent) is lower than that of food, higher fuel prices } \\
\text { would hold back the economic growth and worsen } \\
\text { the current account balance. }\end{array}$ \\
\hline Fiscal sustainability risks & $\begin{array}{l}\text { High } \\
\text { Declining reform momentum and } \\
\text { political will would lead to delay } \\
\text { in delivering the necessary fiscal } \\
\text { reforms. }\end{array}$ & $\begin{array}{l}\text { High } \\
\text { Lack of progress in tax and expenditure reforms } \\
\text { would undermine the public confidence in the fiscal } \\
\text { sustainability and lead to acceleration of outward } \\
\text { migration. It could result in the disruption of } \\
\text { provision of public services in the long run. }\end{array}$ \\
\hline Financial sector risks & $\begin{array}{l}\text { Low } \\
\text { Slowdown of the economy could } \\
\text { increase credit risks and NPLs at } \\
\text { banks. }\end{array}$ & $\begin{array}{l}\text { Medium } \\
\text { Economic slowdown could result in increased credit } \\
\text { risks and NPLs at banks as many households are } \\
\text { heavily indebted with short-term consumer loans. }\end{array}$ \\
\hline
\end{tabular}

1/ The Risk Assessment Matrix (RAM) shows events that could materially alter the baseline path (i.e., which is the scenario most likely to materialize in the view of IMF staff). The relative likelihood of risks listed is the staff's subjective assessment of the risks surrounding this baseline. The RAM reflects staff's views on the source of risks and overall level of concerns as of the time of preparation of this document. 


\section{APPENDIX II. MICRONESIA-LONG-TERM FISCAL SUSTAINABILITY}

This appendix assesses the FSM's long-term fiscal sustainability, updating the estimates in the 2010 Article IV consultation. The analysis considers implications of the expected expiry of annual Compact grants on the fiscal sustainability of the FSM and possible policy options to address the challenge. Fiscal sustainability is considered achieved if the government's financial asset level at end-FY2023 would generate an investment income large enough to replace expiring Compact grants without significantly disrupting public services and eroding the value of the Compact Trust Fund (CTF). ${ }^{1}$

The CTF has exhibited a volatile investment performance over FY2008-12. For FY2008-09, net return on assets was negative by a cumulative 17 percent, substantially eroding the market value of the CTF. Over the period of FY2010-12, the average annual rate of return improved to about $7 \frac{1}{2}$ percent in line with improved financial market conditions, bringing the value of the CTF to $\$ 257$ million as of end-FY2012. As of end-FY2012, financial assets of the CTF are invested into U.S. equity (30 percent), non-U.S. equity (30 percent), fixed income investment ( 22 percent), real estate (7 percent), hedge fund (4 percent), and private equity (8 percent).

Prospects for achieving long-term fiscal sustainability are assessed by presenting several adjustment scenarios against the baseline. The baseline scenario features limited fiscal adjustment and structural reforms, while alternative scenarios consider comprehensive reforms, including implementation of tax and expenditure reforms as well as structural reforms. Throughout all scenarios, net investment returns on the CTF assets are assumed to be 6 percent, in line with an earlier GAO study.

\section{Baseline Scenario}

The baseline scenario assumes that small medium-term fiscal surplus (around $1 / 2$ percent of GDP), similar to those in recent years, will continue over the medium term, as expenditure adjusts to the declining Compact grants. Medium-term real growth is expected to be low at about $1 / 2$ percent, reflecting sluggish investment, continued outmigration, and low productivity growth.

Under the baseline, the CTF would not generate sufficient investment income to replace the annual Compact grants expiring in FY2023. By end-FY2023, the stock of financial assets would be about $\$ 840$ million (in FY2011 dollars), of which $\$ 770$ million would be in the CTF and about $\$ 70$ million in other funds. ${ }^{23}$ During the drawdown phase beginning FY2024, investment income would be about $\$ 50$ million per year compared to $\$ 66$ million of expiring Compact grants in FY2024,

\footnotetext{
${ }^{1}$ The Compact Trust Fund for the FSM was created to contribute to the long-term budgetary self-reliance of the FSM and to provide the FSM government with an ongoing source of revenue after FY2023. The amended Compacts and their subsidiary agreements contain no commitments, either express or implied, regarding the level of the revenue that will be generated by the trust fund, nor is there any commitment regarding the degree to which the revenue will contribute to the long-term budgetary self-reliance of the FSM.

${ }^{2}$ All the amounts in this appendix are based on FY2011 prices, unless otherwise stated.

${ }^{3}$ Government reserves in various funds are assumed to be invested and contribute to closing the revenue gap.
} 
leaving a shortfall of about 5 percent of FY2011 GDP. ${ }^{4}$ With no firm commitment of grants beyond FY2023 and lack of vibrant private sector activity, the government would be forced to either sharply tighten the budget or rapidly deplete its accumulated savings.

Higher investment returns could narrow the shortfall, but simply relying on high returns over a long horizon is not recommended. To generate sufficient investment income to offset the expiring Compact grants, the net investment returns would need to remain at 7.2 percent per year until FY2023. While the CTF has recorded high investment returns in several years, given the high volatility in its performance, it is not advisable to expect as the baseline continuation of such high investment returns over a long period.

\section{Policy Adjustment Scenarios}

Fiscal sustainability can be achieved through significant fiscal adjustments and structural reforms to promote private-sector growth. In policy adjustment scenarios, the government would accumulate savings by fortifying the recent fiscal surplus through comprehensive tax reform and cuts in wasteful current expenditures. According to the PFTAC preliminary estimates, the planned tax reform could improve tax revenue by about 4 percent of GDP. In parallel, it is assumed as in the previous report that structural reforms (e.g., improved education, and other development needs) and accelerated utilization of infrastructure grants will boost potential growth to about $2 \frac{1}{2}$ percent in the medium term despite fiscal consolidation.

\section{i) Swift adjustment scenario}

Model simulations indicate that long-term fiscal sustainability would be achieved by gradually increasing fiscal surpluses by about $1 \frac{114}{4}$ percent of GDP per annum for four years to reach 6.4 percent of GDP in FY2016, and maintaining that level until FY2023. The budget would need to run a surplus sufficient to keep the real value of the fund after FY2023.

Under this swift adjustment scenario, the stock of government assets (including

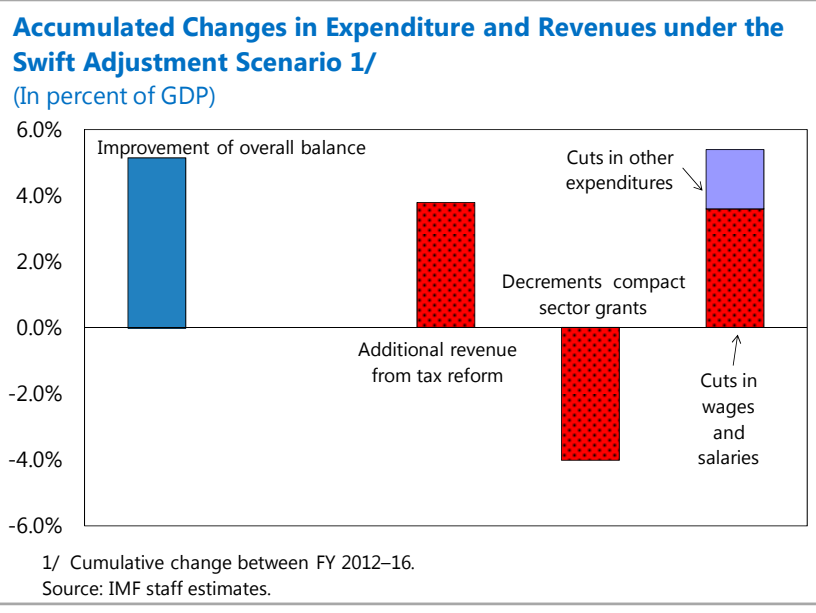
cumulative earnings from these fiscal surpluses) would reach about $\$ 1.1$ billion by the end of the Compact period in FY2023, thus generating sufficient income to offset the expiring Compact grants. The required fiscal adjustment is higher than that in the 2010 Article IV Staff Report by about $1 / 2$ percent of GDP, which reflects a shorter accumulation period until FY2023 (see text charts).

Given the federated system of the FSM, where fiscal surplus of each state belongs to itself, all states need to accumulate their own fiscal surpluses and contribute to closing the revenue gap.

\footnotetext{
${ }^{4}$ The shortfall would be even larger at about 10 percent of GDP if the Supplemental Education Grants (SEG) is discontinued after FY2023.
} 


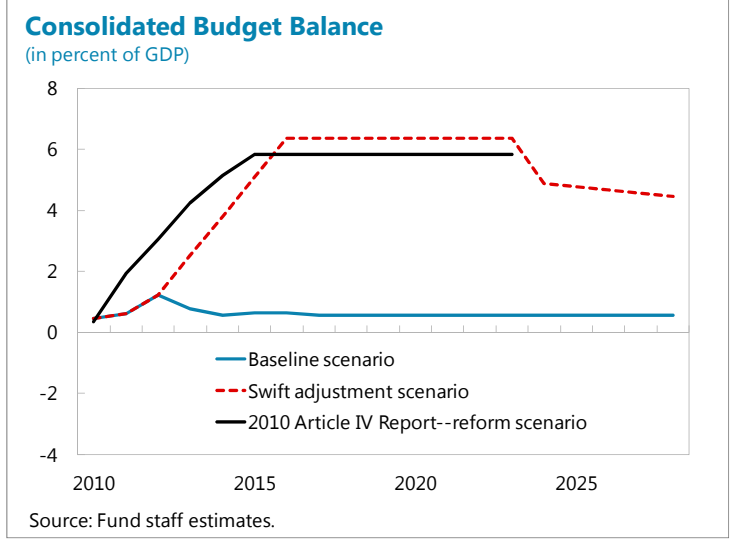

Consolidated Government Asset Value 1/ (in millions of 2011 dollars)

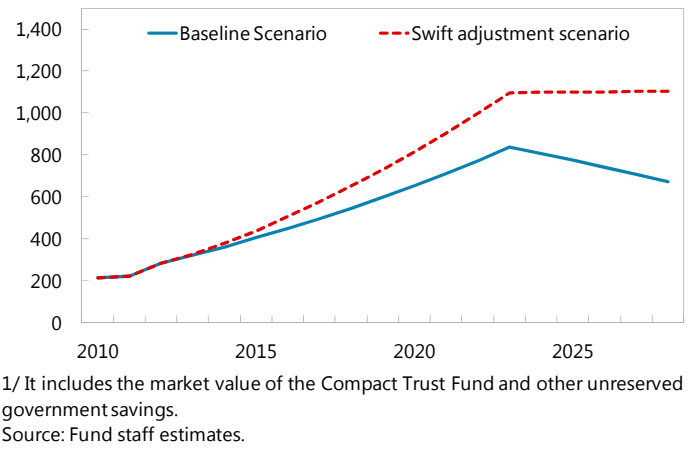

\section{ii) Gradual Adjustment Scenario}

Alternatively, the government could accumulate fiscal surpluses more gradually over a longer period than the swift adjustment scenario. A higher overall level of fiscal surplus would however be required given the slower accumulation process of assets until FY2023. To illustrate this point the scenario assumes an adjustment over eight years rather than four years. Fiscal surpluses would need to be increased by 0.8 percent of GDP per annum until they reach 7.8 percent of GDP in FY2020, and then maintained at that level until FY2023. The expected amount of the CTF assets in FY2023 is the same as under the swift adjustment scenario.

Table 1. Required Fiscal Adjustments for Sustainability

\begin{tabular}{|c|c|c|c|c|}
\hline \multirow[b]{2}{*}{ Scenarios } & \multirow{2}{*}{$\begin{array}{c}\text { Medium-term } \\
\text { overall fiscal } \\
\text { balance }\end{array}$} & \multirow{2}{*}{$\begin{array}{c}\begin{array}{c}\text { Total required } \\
\text { adjustment compared } \\
\text { to FY2012 1/ }\end{array} \\
\text { in percent of GDP }\end{array}$} & \multicolumn{2}{|c|}{$\begin{array}{c}\text { Average annual fiscal adjustment } \\
1 /\end{array}$} \\
\hline & & & $\begin{array}{l}\text { in percent of } \\
\text { GDP }\end{array}$ & $\begin{array}{l}\text { in USD millions } \\
\text { (2011 prices) }\end{array}$ \\
\hline 1 Baseline scenario: no policy change & 0.6 & - & - & - \\
\hline 2 Swift adjustment scenario 1 / & 6.4 & 5.1 & 1.3 & 4.0 \\
\hline if fiscal reforms are delayed by one year & 7.0 & 5.8 & 1.4 & 4.5 \\
\hline 3 Gradual adjustment scenario 1/ & 7.8 & 6.6 & 0.8 & 2.6 \\
\hline
\end{tabular}

1/ Required fiscal adjustments to supplement Compact sector grants (excluding SEG and audit grants)

without significantly disrupt public services when those grants expire by FY2024.

Source: Fund staff estimates.

\section{iii) Risk Analysis}

\section{Delays in implementing fiscal reforms would} increase the required adjustments. If the implementation of fiscal reforms under the swift adjustment scenario is delayed by one year, the medium term fiscal surplus required to achieve the sustainability would be 7.0 percent of GDP, higher by 0.6 percentage points, thus requiring even more challenging adjustments (see text chart).

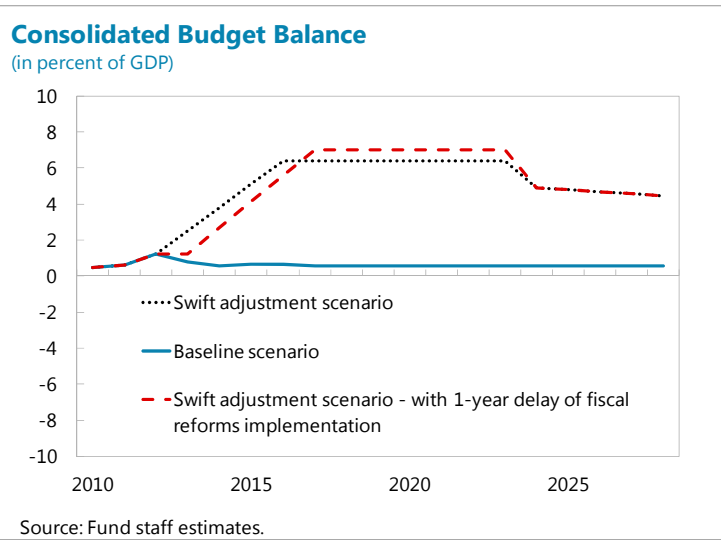


In addition, if the growth is assumed to be $1 \frac{1}{2}$ percent, rather than $2 \frac{1}{2}$ percent, the required fiscal surplus in FY2016 under the swift adjustment scenario would be 6.7 percent of GDP, higher by 0.3 percentage points. If the net investment return is assumed to be 5 percent, rather than 6 percent, the required fiscal surplus in FY2016 under the swift adjustment scenario would be 12.0 percent of GDP, bringing the total adjustment needed to about twice that under the initial assumption. These sensitivity analyses underline the importance of swiftly implementing reforms and building policy buffers. 


\section{INTERNATIONAL MONETARY FUND}

\section{FEDERATED STATES OF MICRONESIA}

\section{STAFF REPORT FOR THE 2012 ARTICLE IV}

Prepared By

\section{CONTENTS}

ANNEX I. FUND RELATIONS 2

ANNEX II. RELATIONS WITH THE WORLD BANK GROUP (OR BANK-FUND COLLABORATION). 3

ANNEX III. RELATIONS WITH THE ASIAN DEVELOPMENT BANK (ASDB). 5

ANNEX IV. RELATIONS WITH THE PACIFIC FINANCIAL TECHNICAL ASSISTANCE CENTRE (PFTAC)—COUNTRY STRATEGY 2012-14........ 7

ANNEX V. STATISTICAL ISSUES. 9 


\section{ANNEX I. FUND RELATIONS}

(As of November 30, 2012)

I. Membership Status: Joined June 24, 1993; accepted Article VIII.

II. General Resources Account:

Quota

Fund holdings of currency

Reserve position in Fund

III. SDR Department:

Net cumulative allocation

Holdings

SDR Million
5.10
5.10
0.00

SDR Million
4.81
6.23

6.23

$$
\begin{gathered}
\text { Percent Quota } \\
100.00 \\
100.00 \\
0.01
\end{gathered}
$$

Percent Allocation

100.00

129.55

IV. Outstanding Purchases and Loans: None.

V. Financial Arrangements: None.

VI. Projected Obligations to Fund: None.

VII. Exchange Rate Arrangement:

The U.S. dollar is legal tender and the official currency. The Federated States of Micronesia (FSM) maintains an exchange system that is free of restrictions on international payments and transfers for current and capital transactions except for security reasons.

VIII. Article IV Consultation:

The Federated States of Micronesia (FSM) is on the 24-month consultation cycle. The 2010 Article IV consultation discussions took place during November 8-17, 2010. The Executive Board discussed the staff report (Country Report No. 11/43) and concluded the consultation on January 26, 2011.

IX. Technical Assistance, 1999-2010:

STA, MCM, LEG, and PFTAC have provided technical assistance on statistics, banking supervision, tax policy, and combating of financial crime and financial system abuse.

X. Resident Representative: Mr. Yongzheng Yang assumed his duties as the Resident Representative for Pacific Island Countries on September 13, 2010. He is based in Suva, Fiji. 


\section{ANNEX II. RELATIONS WITH THE WORLD BANK GROUP (OR BANK-FUND COLLABORATION)}

The Bank and the Fund country teams maintain a close working relationship and have an ongoing dialogue on a range of macroeconomic and structural issues.

The teams agreed that FSM's main macroeconomic challenges are to increase budgetary selfreliance-as Compact support is due to expire in FY2023, while enhancing the prospects for private sector development. To achieve these goals, FSM needs to undertake sustainable fiscal reform, while improving the overall business environment.

Based on this shared assessment, the teams identified the following structural reform areas as macro-critical, in view of their central role in achieving fiscal consolidation and sustained growth:

(i) Comprehensive revenue reform. Sales and income taxes collected by the FSM government are below that of other Pacific Island countries. Enhancing revenues is one avenue towards achieving a more sustainable path for public finance. Although progress has been made over the past 2 years, the government's tax reform package - which includes the introduction of a VAT and a net profits tax, and establishment of the Unified Revenue Authority (URA) - has yet to pass the Congress. The successful tax reform would also benefit the private sector by improving efficiency. Reform of the public financial management should proceed in tandem to complement and protect the benefits of fiscal reforms.

(ii) Reform of the public enterprises. Public enterprises pose a burden on FSM's budget, while possibly crowding out private firms. They pay higher wages than in the private sector and in government agencies, receive subsidized government loans, and are not subject to the gross revenue tax. The government has taken some steps, including the shutdown of insolvent enterprises such as the National Fisheries Corporation, but more could be done.

(iii) Financial sector reform. Commercial banks are cautious to lend to local businesses despite their ample liquidity. Part of the reason is the inherent risk of start-up lending, the high fixed costs associated with small loans, and the difficulties in collecting on collateral. Moreover, the FSM Development Bank continues to lend to well-established firms and consumers, rather than supporting start-ups. To improve access to credit, it is necessary to redirect the focus of the FSM Development Bank, expand micro-credit through credit unions and micro-credit agencies while ensuring their supervision, and improve the functioning of the secured transaction framework.

(iv) Reform of the statistical system. Limited domestic capacity to produce economic data prevents understanding of the contribution to the economy of sectors as tourism, fisheries and agriculture, making difficult timely policy response to any shocks to those sectors. Strengthening the statistical capacity is macro-critical, because timely and reliable provision of data is required to assess the economic conditions appropriately and to make necessary policy decisions accordingly.

The teams agreed to continue the close cooperation going forward. Appendix I details the specific activities planned by the two country teams over the period October 2012 - September 2013 along with their expected deliveries. The Bank has reclassified FSM from an IBRD to an IDA-eligible country in 2011. This reclassification will have implications for the Bank's potential lending program and the relevant outcomes of discussions with the government will be shared with the Fund team. 
Appendix I. Micronesia: Bank and Fund Planned Activities in Macro-critical Structural Reform Areas (October 2012-September 2013)

\begin{tabular}{|c|c|c|c|}
\hline Title & Products & $\begin{array}{l}\text { Provisional Timing of } \\
\text { Missions }\end{array}$ & $\begin{array}{l}\text { Expected Delivery } \\
\text { Date (tentative) }\end{array}$ \\
\hline \multicolumn{4}{|c|}{ A. Mutual Information on Relevant Work Programs } \\
\hline $\begin{array}{l}\text { Bank work } \\
\text { program }\end{array}$ & $\begin{array}{l}\text { Bank-only Debt Sustainability Analysis } \\
\text { (with input from Fund) } \\
\text { Country Partnership Strategy } \\
\text { Possible ICT Project- work towards } \\
\text { liberalization and the introduction of } \\
\text { competition in the telecommunications } \\
\text { sector, through TA and a regional } \\
\text { Lending Operation. }\end{array}$ & $\begin{array}{l}\text { November } 2012 \\
\text { January } 2013 \\
\text { January } 2013 \\
\text { March } 2013 \\
\text { June } 2013 \\
\text { September } 2013\end{array}$ & $\begin{array}{l}\text { FY2013 } \\
\text { FY2014 } \\
\text { FY2014 }\end{array}$ \\
\hline $\begin{array}{l}\text { IMF work } \\
\text { program }\end{array}$ & 2012 Article IV Mission & November 2012 & $\begin{array}{l}\text { Board Discussion } \\
\text { expected in January } \\
2013\end{array}$ \\
\hline \multicolumn{4}{|c|}{ B. Request for Work Program Inputs } \\
\hline $\begin{array}{l}\text { Fund request to } \\
\text { Bank }\end{array}$ & $\begin{array}{l}\text { Assessment of macroeconomic } \\
\text { developments and policies } \\
\text { Information sharing }\end{array}$ & $\begin{array}{l}\text { Semi-annual or more } \\
\text { frequent } \\
\text { Semi-annual or more } \\
\text { frequent }\end{array}$ & $\begin{array}{l}\text { Ongoing } \\
\text { Ongoing }\end{array}$ \\
\hline $\begin{array}{l}\text { Bank request to } \\
\text { Fund }\end{array}$ & $\begin{array}{l}\text { Assessment of macroeconomic } \\
\text { developments and policies }\end{array}$ & $\begin{array}{l}\text { Semi-annual or more } \\
\text { frequent }\end{array}$ & Ongoing \\
\hline & Information and macro data sharing & $\begin{array}{l}\text { Semi-annual or more } \\
\text { frequent }\end{array}$ & Ongoing \\
\hline \multicolumn{4}{|c|}{ C. Agreement on Joint Point Products and Missions } \\
\hline $\begin{array}{l}\text { Joint Work } \\
\text { Program }\end{array}$ & Debt Sustainability Analysis & Tentative & Ongoing \\
\hline
\end{tabular}




\section{ANNEX III. RELATIONS WITH THE ASIAN DEVELOPMENT BANK (ASDB)}

The Federated States of Micronesia became a member of the AsDB in 1990, and has received a substantial amount of assistance since that time. As at December 2011, the FSM has received eight loans, 1 grant, and 43 TA grants. ${ }^{1}$

The AsDB has assisted the FSM by (i) supporting infrastructure development; (ii) supporting public sector management, with a particular focus on economic management and accountability; (iii) ensuring inclusive social development; and (iv) promoting sustained private sector-led economic growth. The approach of the ADB has been to focus on a few key constraints: careful analysis of the political economy; a preparedness to closely manage and support operations; a move away from complex federally administered and state delivered multistate and multi-sector projects; adoption of home grown solutions; and simple and realistic project outcomes.

Under AsDB's country operations business plan for 2013-2015, which is currently under discussion with the authorities, support will be formulated in the context of the "Action Plan 2023" and the "Development Framework", as presented at the recent FSM Development Partners Forum. Attention will be given to supporting infrastructure development, especially power sector development and transport. Key pipeline initiatives include the Yap Renewable Energy Project, the Pohnpei Energy Sector project and the Pohnpei Port Development project. AsDB will also support a long term, and well-coordinated approach to strengthening public financial management, including through a recently approved technical assistance to develop capacity for sector investment planning in infrastructure. Further, AsDB will provide capacity development support to the education sector, in close coordination with the financial support provided from Compact. Finally, AsDB is discussing a "binding constraints assessment" in the tourism sector.

Currently there are two active loans. The Omnibus Infrastructure Development project loans (totaling $\$ 19 \mathrm{~m}$ ), approved in 2004 , are designed to enhance public health, environmental quality, and surface water quality through improved wastewater infrastructure and management for Pohnpei and improved delivery of water services and expanded water supply systems for Yap and Kosrae; and improved management and provision of power in Chuuk.

AsDB's non-lending program has focused on improving public sector efficiency, effectiveness, and accountability, as well as raising public awareness through community consultation and participation programs, particularly in Chuuk and Kosrae. Further Technical assistance will be provided to provide for capacity building in project management and procurement processes to support infrastructure development.

\footnotetext{
${ }^{1}$ The eight loans are for: (i) fisheries development; (ii) law, economic management and public policy; (ii) water supply and sanitation; (iv) basic social services; and (v) private sector development. No loans to FSM in 2008-10.
} 
Table 1. Loans to the Federated States of Micronesia by Sector (In millions of U.S. dollars; as of December2011)

\begin{tabular}{lrr}
\hline Sector & No. & Amount \\
\hline Agriculture and Natural Resources & 1.0 & 6.5 \\
Energy & 0.0 & 0.0 \\
Industry and Nonfuel Minerals & 0.0 & 0.0 \\
Transportation & 0.0 & 0.0 \\
Communications & 0.0 & 0.0 \\
Law, Economic Management and Public Policy & 3.0 & 31.0 \\
Water Supply, Sanitation \& Waste Management & 1.0 & 10.6 \\
Multisector & 3.0 & 27.0 \\
Other & 0.0 & 0.0 \\
Total & & \\
Memorandum Item: & 8.0 & 75.1 \\
Technical Assistance Provided & &
\end{tabular}

Table 2. Loan Approvals and Disbursements to the FSM, 2002-11

(In millions of U.S. dollars)

\begin{tabular}{lllllllllll}
\hline $1990-$ \\
2002 & 2003 & 2004 & 2005 & 2006 & 2007 & 2008 & 2009 & 2010 & 2011 & 2011 \\
\hline
\end{tabular}

\begin{tabular}{|c|c|c|c|c|c|c|c|c|c|c|c|}
\hline $\begin{array}{l}\text { Loan Approvals } \\
\text { Loan }\end{array}$ & 0.0 & 0.0 & 19.0 & 0.0 & 0.0 & 0.0 & 0.0 & 0.0 & 0.0 & 0.0 & 75.1 \\
\hline Disbursements & 1.4 & 2.7 & 1.1 & 1.7 & 2.5 & 3.6 & 3.6 & 0.8 & 1.1 & 6.3 & 49.5 \\
\hline $\begin{array}{l}\text { Undisbursed } \\
\text { balance at the e } \\
\text { of the year }\end{array}$ & 22.0 & 19.2 & 18.1 & 16.4 & 13.9 & 10.3 & 6.8 & 6.0 & 17.7 & 11.5 & \\
\hline Memorandum & & & & & & & & & & & \\
\hline TA Approvals & 1.0 & 1.2 & 0.85 & 0.0 & 0.6 & 0.4 & 0.8 & 0.0 & 0.0 & 0.7 & 25.7 \\
\hline
\end{tabular}




\section{ANNEX IV. RELATIONS WITH THE PACIFIC FINANCIAL TECHNICAL ASSISTANCE CENTRE (PFTAC)—COUNTRY STRATEGY 2012-14}

\section{Background}

FSM has rebounded well from the global economic crisis but needs to take continued action to safeguard long term fiscal sustainability. The economic recovery is expected to continue in the near term supported by ongoing construction activities and expansion of the fisheries sector, but faces headwinds over the medium-term from the scheduled declines in Compact sector grants. Continued efforts to advance tax reforms, targeted expenditure cuts, and structural reforms to nourish private sector growth are essential to secure long-term fiscal and economic sustainability.

FSM has been a moderate user of PFTAC Technical Assistance (TA). The most significant input has been in the revenue area where PFTAC has supported the design of revenue policy and administration reforms, including the drafting of legislation that awaits approval. There has also been input in PFM, most recently through support for a PEFA assessment, and financial sector supervision.

\section{Strategy 2012-14}

PFTAC's TA strategy is guided by the APD regional strategy note and is planned within the results framework for current PFTAC funding cycle.

PFTAC TA aims to support the authorities continue to move towards long-term fiscal sustainability. Activities will focus on assisting the authorities achieve tangible results from the foundations laid with previous PFTAC assistance, and will include strategic support in the PFM area and continued input on revenue, in coordination with AusAID. Financial sector work will also continue, with a possible expansion into the insurance sector.

In the Public Financial Management area, the focus will be on completing the PEFA assessment (1.1) and supporting the authorities develop a PFM roadmap (1.2). Activities to support the roadmap's implementation will be planned in coordination with other partners, in particular the ADB, but are expected to include strengthened cash management (1.6).

In the revenue area, the nature of assistance will be dependent on the approval of tax reforms designed with PFTAC-assistance (2.1). PFTAC will coordinate closely with and support an AusAIDfunded resident advisor who will be responsible for day to day support to the tax administration. Assuming the reforms go ahead, PFTAC will also deliver support on specific technical areas, including further development and implementation of an IT strategy (2.3), additional legislative drafting (2.1) and in the more medium-term corporate planning $(2,2)$ and compliance improvement strategies (2.6).

FSM's economic statistics are mainly produced by Compact-funded projects and input is therefore expected to be relatively limited in this area in the short-term. Provided adequate staffing remains available in the statistics office, PFTAC will look to support enhancements in the 
range of national accounts aggregates that are produced (4.3) and provide hands-on training in compilation methods while IMF HQ will offer support on balance of payments development (4.7).

In financial sector supervision, PFTAC will focus on assisting the Banking Commission to modernize the Banking Act (3.8) and to strengthen off-site reporting through the adoption of enhanced prudential returns and better, more-automated analysis (3.1, 3.2, 3.3). Strengthening of the ability to assess banks on a CAMELS basis (3.4) will also continue. PFTAC will coordinate with IMF HQ and other TA providers to ensure that the newly-formed insurance commission has access to suitable capacity building but is unlikely to be able to devote significant resources to this area given resource constraints and that insurance does not feature in Phase IV's results framework.

In macroeconomics, no direct input is currently anticipated. However, support to forecasting of long-term economic scenarios may be provided in late 2013. 


\section{ANNEX V. STATISTICAL ISSUES}

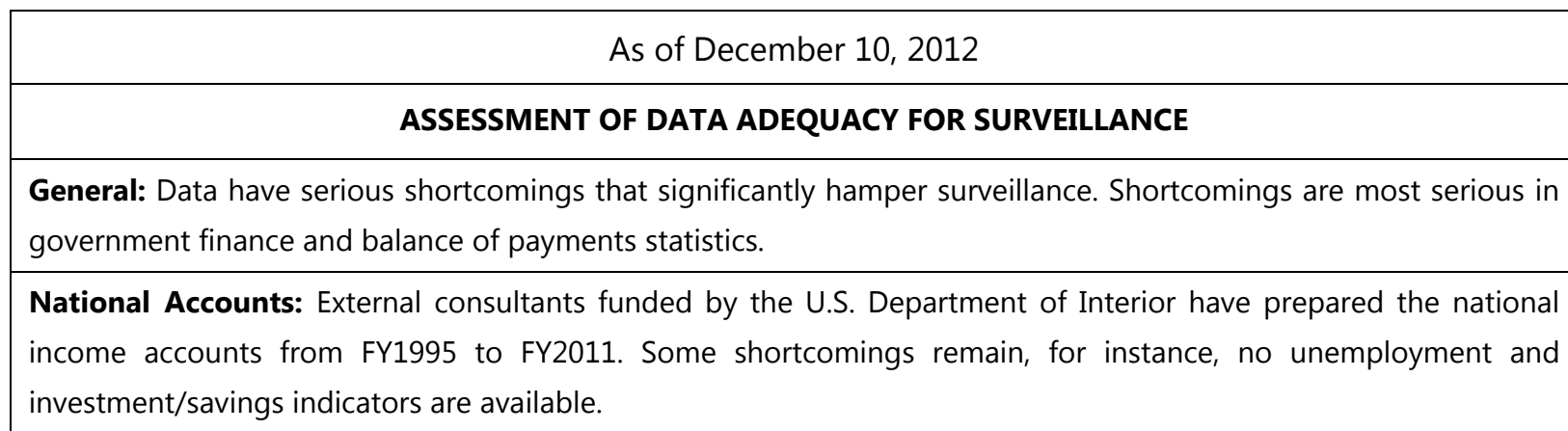

Price statistics: A quarterly consumer price index (CPI) -rebased to Q2 2008 and utilizing expenditure weights derived from an earlier household survey- is published for the Federated State of Micronesia (FSM) as a whole and for each state. However, the data releases suffer from considerable lags, which prevent an accurate and timely evaluation of domestic price movements. For instance, the FY2012 consumer price index has not yet been finalized.

Government finance statistics: The national and the state governments and public sector enterprises publish annual audit reports detailing their fiscal operations; consultants put these data in a GFS format with a lag of about one year. The accuracy of the tax revenue data compiled by the authorities needs improvement as they are sometimes different from the audit reports. Further improvements in the quality and timeliness of the fiscal data depend on greater cooperation between the national and state governments. Micronesia does not present fiscal data using the Government Finance Statistics Manual 2001 (GFSM 2001) format.

Monetary statistics: The Banking Commissioner reports monthly monetary data to STA with a two- to threemonth lag. The data comprise interest rates, the accounts of the monetary authorities, commercial banks, and the FSM Development Bank. The Commissioner has taken the view that the banking law prevents the sharing of this information outside the Banking Board, hampering domestic surveillance.

Balance of payments: The Office of Statistics, Budget \& Economic Management, Overseas Development Assistance and Compact Management (SBOC) publishes annual estimates of the balance of payments and external debt statistics. The data on workers' remittances are highly incomplete. Delays of data release impart a high degree of uncertainty to analysis of external sector developments. The SBOC aims to produce quarterly balance of payments statistics and to introduce new data sources, such as surveys. Micronesia participates in the JSA Project on the Improvement of External Sector Statistics in the APD region.

\section{DATA STANDARDS AND QUALITY}

Micronesia does not participate in the IMF's General Data Dissemination System. No data ROSC is available.

REPORTING TO STA (OPTIONAL)

Only international liquidity and monetary statistics are currently reported to STA for publication in the International Financial Statistics (IFS). Micronesia does not submit balance of payments data to STA for publication in the IFS or the Balance of Payments Statistics Yearbook (BOPSY). 
MICRONESIA: TABLE OF COMMON INDICATORS REQUIRED FOR SURVEILLANCE AS OF DECEMBER 10, 2012

\begin{tabular}{|c|c|c|c|c|c|}
\hline & $\begin{array}{c}\text { Date of } \\
\text { latest } \\
\text { observation }\end{array}$ & $\begin{array}{l}\text { Date } \\
\text { received }\end{array}$ & $\begin{array}{c}\text { Frequency } \\
\text { of } \\
\text { Data }^{7}\end{array}$ & $\begin{array}{l}\text { Frequency } \\
\text { of } \\
\text { Reporting }^{7}\end{array}$ & $\begin{array}{l}\text { Frequency } \\
\text { of } \\
\text { publication }^{7}\end{array}$ \\
\hline Exchange Rates & Nov. 2012 & Nov. 2012 & $\mathrm{D}$ & $\mathrm{D}$ & $\mathrm{D}$ \\
\hline $\begin{array}{l}\text { International Reserve Assets and Reserve Liabilities } \\
\text { of the Monetary Authorities } 1\end{array}$ & Aug. 2012 & Nov. 2012 & M & M & M \\
\hline Reserve/Base Money & Aug. 2012 & Nov. 2012 & M & M & NA \\
\hline Broad Money & Aug. 2012 & Nov. 2012 & M & M & NA \\
\hline Central Bank Balance Sheet & Aug. 2012 & Nov. 2012 & M & M & NA \\
\hline Consolidated Balance Sheet of the Banking System & Aug. 2012 & Nov. 2012 & M & M & NA \\
\hline Interest Rates ${ }^{2}$ & Aug. 2012 & Nov. 2012 & M & M & M \\
\hline Consumer Price Index & 2011Q4 & Aug. 2012 & Q & A & I \\
\hline $\begin{array}{l}\text { Revenue, Expenditure, Balance/Composition of } \\
\text { Financing }{ }^{3} \text { General Government }{ }^{4} \text { and Central } \\
\text { Government }\end{array}$ & FY2011 & Aug. 2012 & $A$ & A & A \\
\hline $\begin{array}{l}\text { Stocks of Central Government and Central } \\
\text { Government-Guaranteed Debt }\end{array}$ & $\mathrm{N} / \mathrm{A}$ & $\mathrm{N} / \mathrm{A}$ & $\mathrm{N} / \mathrm{A}$ & $\mathrm{N} / \mathrm{A}$ & $\mathrm{N} / \mathrm{A}$ \\
\hline External Current Account Balance & FY2011 & Aug. 2012 & $A$ & $A$ & I \\
\hline Exports and Imports of Goods and Services & FY2011 & Aug. 2012 & $A$ & A & I \\
\hline GDP/GNP & FY2011 & Aug. 2012 & A & $A$ & I \\
\hline Gross External Debt & FY2011 & Aug. 2012 & $A$ & $A$ & I \\
\hline International Investment Position ${ }^{6}$ & FY2011 & Aug. 2012 & $A$ & A & A \\
\hline
\end{tabular}

1 Any reserve assets that are pledged of otherwise encumbered should be specified separately. Also, data should comprise shortterm liabilities linked to a foreign currency but settled by other means as well as the notional values of financial derivatives to pay and to receive foreign currency, including those linked to a foreign currency but settled by other means.

2 Include the interest rates on consumer loans and commercial loans. Deposit rates are received annually with latest observation for 2011.

3 Foreign, domestic bank, and domestic nonbank financing.

4 The general government consists of the central government (budgetary funds, extra budgetary funds, and social security funds) and state and local governments.

5 Including currency and maturity composition.

6 Includes external gross financial asset and liability positions vis-à-vis nonresidents.

7 Daily (D), Weekly (W), Monthly (M), Quarterly (Q), Annually (A); Irregular (I); Not Available (NA) 


\section{INTERNATIONAL MONETARY FUND}

EXTERNAL

RELATIONS

Public Information Notice

DEPARTMENT

Public Information Notice (PIN) No. 13/06

FOR IMMEDIATE RELEASE

January 17,2013
International Monetary Fund

$70019^{\text {th }}$ Street, NW

Washington, D. C. 20431 USA

\section{IMF Executive Board Concludes 2012 Article IV Consultation with Federated States of Micronesia}

On January 14, 2013, the Executive Board of the International Monetary Fund (IMF) concluded the Article IV consultation with the Federated States of Micronesia (FSM). ${ }^{1}$

\section{Background}

The FSM's economy is highly dependent on external aid, and private activity contributes little to growth. A new Compact of Free Association agreement ("Compact") with the United States, effective since Fiscal Year (FY) 2004, steadily lowers transfers to the FSM through FY2023 and has stricter rules on the use of grants. After FY2023, the FSM is expected to complement its domestic revenues with income from its Compact Trust Fund (CTF) and other savings.

Since the last Article IV consultation, the economy continued on a steady growth path. Following a recession in FY2006-2008 due to delay in Compact grants utilization as well as high fuel and food prices, the FSM economy grew by 2-2 $\frac{1}{2}$ percent for FY2010 and FY2011. The expansion was driven by new construction activities and growth of the fishery sector. Inflation has declined to 4.6 percent in FY2011, after reaching its recent peak of 7.8 percent in FY2009.

The overall fiscal balance of the consolidated government recorded modest surpluses for three straight years through FY2011, with an uneven distribution of outcomes across states. Public debt remains at a relatively low level (below 30 percent of GDP), but underfunding in the CTF assets and a declining balance of the social security fund pose long-term challenges.

\footnotetext{
${ }^{1}$ Under Article IV of the IMF's Articles of Agreement, the IMF holds bilateral discussions with members, usually every year. A staff team visits the country, collects economic and financial information, and discusses with officials the country's economic developments and policies. On return to headquarters, the staff prepares a report, which forms the basis for discussion by the Executive Board. At the conclusion of the discussion, the Managing Director, as Chairman of the Board, summarizes the views of Executive Directors, and this summary is transmitted to the country's authorities. An explanation of any qualifiers used in summing up can be found here: http://www.imf.org/external/np/sec/misc/qualifiers.htm.
} 
Despite some deterioration of the current account balance, external balance is sustained by a stable flow of official transfers. The majority of the overall current account deficit is financed through capital transfers from official sources.

Economic growth will likely slow in the near term, as the private sector falls short of offsetting the declining public sector demand from Compact grants reduction. Growth in FY2012 is estimated at 1.4 percent as recent construction projects are winding down. A modest consolidated fiscal surplus of 11/4 percent of GDP is expected in FY2012, mainly due to a sharp increase in fishing access fee revenue by $\$ 7.6$ million. While the fishery sector is expected to continue its healthy expansion, lackluster wholesale and retail activities will remain a drag on the private sector growth. Beyond the near-term, growth is weighed down by the scheduled reduction in Compact grants. Medium-term growth is estimated to stay low at about $1 / 2$ percent, with limited private sector growth failing to offset the effects of a decline in Compact grants.

\section{Executive Board Assessment}

Executive Directors noted that the FSM economy continued to grow last year, driven by construction and fishery. Nonetheless, the economy faces important risks, including from a potential deterioration in the external environment and, over the longer term, the scheduled expiration of Compact grants and the continued outmigration of the working age population. In this context, Directors underscored the need to begin addressing the fiscal gap to create fiscal buffers and ensure sustainable public finances, and to accelerate reforms to boost potential growth.

Directors encouraged the authorities to implement a credible fiscal strategy based on a realistic macroeconomic framework and balanced fiscal adjustment. They stressed the importance of swift passage of the comprehensive tax reform bill to enhance revenue, and the need to contain current expenditures, in particular public wages. It will also be essential to improve public financial management to complement tax and expenditure reforms.

Directors cautioned that underfunding of the Compact Trust Fund and a declining balance of the social security fund pose long-term challenges. With the Compact grants scheduled to expire in FY2023, Directors underlined the importance of improving FSM's capacity to fully utilize the remaining grants. They encouraged the authorities to prepare for the grants' expiration by developing realistic reform plans with broad support from the state governments and the general public. In this regard, they looked forward to swift approval of the budget to establish the 2023 Planning Committee.

Directors emphasized the importance of advancing investment-friendly reforms to catalyze growth and support fiscal consolidation. In this context, further liberalizing land use and lease and streamlining investment licensing procedures at the national and state levels are important priorities.

Directors noted that the financial system is well capitalized and liquid, but urged careful monitoring of credit quality given the increase in consumer loans in recent years. They welcomed efforts to address issues in loan collateral, which could help unlock commercial 
lending. Directors agreed that the FSM Development Bank should be brought under appropriate supervision and its activities redirected to helping finance start-ups.

Directors encouraged the authorities to step up production of high quality economic statistics, especially in the fiscal area, to strengthen monitoring and policy analysis.

Public Information Notices (PINs) form part of the IMF's efforts to promote transparency of the IMF's views and analysis of economic developments and policies. With the consent of the country (or countries) concerned, PINs are issued after Executive Board discussions of Article IV consultations with member countries, of its surveillance of developments at the regional level, of post-program monitoring, and of ex post assessments of member countries with longer-term program engagements. PINs are also issued after Executive Board discussions of general policy matters, unless otherwise decided by the Executive Board in a particular case. The staff report (use the free Adobe Acrobat Reader to view this pdf file) for the 2012 Article IV Consultation with Federated States of Micronesia is also available. 
Micronesia: Selected Economic Indicators, FY2008-13 ${ }^{1 /}$

\begin{tabular}{|c|c|c|c|c|c|c|}
\hline & FY2008 & FY2009 & FY2010 & FY2011 & $\begin{array}{l}\text { FY2012 } \\
\text { Est. }\end{array}$ & $\begin{array}{l}\text { FY2013 } \\
\text { Proj. }\end{array}$ \\
\hline \multicolumn{7}{|c|}{ Real sector (average annual percent change unless otherwise noted) } \\
\hline Real GDP & -2.6 & 1.0 & 2.5 & 2.1 & 1.4 & 0.8 \\
\hline Consumer prices & 6.6 & 7.8 & 6.3 & 4.6 & 5.6 & 4.2 \\
\hline Employment & -4.8 & -0.3 & 4.1 & 2.3 & 0.2 & 0.1 \\
\hline Public (incl. public enterprises) & -6.3 & -2.1 & 1.3 & -0.2 & 0.1 & 0.1 \\
\hline Private & -3.5 & 1.7 & 7.4 & 5.0 & 0.3 & 0.2 \\
\hline Nominal wages & 3.7 & 4.2 & 2.5 & 0.1 & 2.7 & 2.7 \\
\hline Public-private wage ratio & 2.1 & 2.2 & 2.2 & 2.1 & 2.1 & 2.1 \\
\hline \multicolumn{7}{|c|}{ Consolidated government finance (in percent of GDP) } \\
\hline Revenue and grants & 57.3 & 65.9 & 68.2 & 65.9 & 65.2 & 62.6 \\
\hline Revenue & 21.2 & 21.4 & 21.8 & 21.8 & 23.3 & 22.0 \\
\hline Grants & 36.1 & 44.5 & 46.3 & 44.1 & 42.0 & 40.6 \\
\hline Expenditure & 59.0 & 64.2 & 67.7 & 65.3 & 64.0 & 61.8 \\
\hline Current & 50.2 & 47.4 & 48.1 & 46.9 & 46.8 & 45.3 \\
\hline Capital & 8.8 & 16.9 & 19.6 & 18.4 & 17.2 & 16.6 \\
\hline Overall balance & -1.7 & 1.6 & 0.5 & 0.6 & 1.2 & 0.8 \\
\hline Compact Trust Fund (millions of U.S. dollars) & 119.1 & 138.3 & 177.2 & 198.5 & 257.4 & 297.5 \\
\hline \multicolumn{7}{|c|}{ Commercial banks (in millions of U.S. dollars; end of period) } \\
\hline Foreign assets & 101.4 & 121.5 & 127.7 & 143.6 & 156.2 & 169.8 \\
\hline Loans & 49.2 & 46.7 & 55.7 & 55.2 & 60.0 & 65.3 \\
\hline Total deposits & 118.9 & 132.5 & 154.1 & 166.2 & 175.2 & 181.8 \\
\hline \multicolumn{7}{|l|}{ Interest rates (in percent, average for FY) } \\
\hline Consumer loans & 14.4 & 15.4 & 15.1 & 14.4 & 15.0 & 14.8 \\
\hline Commercial loans & 8.5 & 7.4 & 6.6 & 6.6 & 8.1 & 7.7 \\
\hline \multicolumn{7}{|l|}{ Balance of payments (in millions of U.S. dollars) } \\
\hline Trade balance & -121.7 & -128.4 & -130.7 & -134.2 & -133.1 & -130.4 \\
\hline Net services and income & -27.6 & -31.3 & -30.1 & -32.4 & -24.5 & -25.6 \\
\hline Private and official transfers & 105.5 & 108.4 & 112.1 & 108.0 & 108.7 & 107.3 \\
\hline \multirow{2}{*}{$\begin{array}{l}\text { Current account including official transfers } \\
\text { (in percent of GDP) }\end{array}$} & -43.8 & -51.3 & -48.7 & -58.6 & -49.0 & -48.7 \\
\hline & -16.7 & -18.5 & -16.6 & -18.9 & -15.0 & -14.3 \\
\hline \multirow{2}{*}{$\begin{array}{l}\text { Current account excluding official transfers } \\
\text { (in percent of GDP) }\end{array}$} & -142.6 & -155.9 & -157.2 & -162.2 & -153.9 & -152.0 \\
\hline & -54.6 & -56.2 & -53.4 & -52.3 & -47.0 & -44.8 \\
\hline \multirow{3}{*}{$\begin{array}{l}\text { Overall balance } \\
\text { (in percent of GDP) } \\
\text { Gross reserves (in months of imports) }\end{array}$} & -3.0 & -1.6 & -0.3 & 0.9 & 6.5 & 0.9 \\
\hline & -1.2 & -0.6 & -0.1 & 0.3 & 2.0 & 0.3 \\
\hline & 2.5 & 2.7 & 2.8 & 3.6 & 3.6 & 3.6 \\
\hline \multicolumn{7}{|c|}{ External debt (in millions of U.S. dollars; end of period) ${ }^{2 /}$} \\
\hline \multirow{2}{*}{$\begin{array}{l}\text { Stock } \\
\quad \text { (in percent of GDP) }\end{array}$} & 74.1 & 84.6 & 84.3 & 87.1 & 87.1 & 87.1 \\
\hline & 28.4 & 30.5 & 28.7 & 28.1 & 26.6 & 25.7 \\
\hline \multirow{2}{*}{$\begin{array}{l}\text { Debt service } \\
\text { (in percent of exports of goods and services) }\end{array}$} & 3.2 & 3.9 & 4.3 & 5.0 & 5.1 & 5.0 \\
\hline & 5.4 & 6.6 & 6.6 & 6.9 & 6.6 & 6.1 \\
\hline \multicolumn{7}{|l|}{ Exchange rate regime } \\
\hline Real effective exchange rate ${ }^{3 /}$ & 97.5 & 106.7 & 108.6 & 107.6 & 108.1 & 108.5 \\
\hline
\end{tabular}

Sources: Data provided by the FSM authorities and IMF staff estimates.

1/ Fiscal year ending September 30. Estimates for FY2012 and projections for FY2013 are preliminary and based on data received from the authorities.

2/ Government and public enterprise debt only.

$3 /$ Year $2000=100$. 


\section{Statement by Jong-Won Yoon, Executive Director for the Federated States of Micronesia, and Branan Karae, Government-Provided, Advisor to the Executive Director January 14, 2012}

Federated States of Micronesia (FSM) authorities thank staff for the constructive policy dialogue and useful advice that was provided during the 2012 Article IV Consultation.

FSM is a small Pacific island country with a population of approximately 112,000 people and consisting of four island states, namely Yap, Chuck, Pohnpei and Kosrae, located across the Western Pacific Ocean. ${ }^{1}$ As a small island nation, the country has relied heavily on the US grants accounting for about a third of its GDP. The Compact grant, however, is on the decline and scheduled to end in 2023. The reduction in the Compact assistance presents the biggest challenge for the future outlook. Given FSM's high dependency on public sector and the difficulties of the private sector to offset a decline in public sector demand from the scheduled reductions in Compact grant, achieving longterm self reliance of budget is becoming an urgent matter.

Despite the stepped up efforts in recent years, a number of challenges remain with more to be accomplished. The authorities broadly agree with staff recommendations on the way forward and reaffirmed their commitment to working with the Fund and development partners, in order to facilitate economic growth and reduce its dependency on external aid support beyond 2023.

\section{Economic Developments and Outlook}

Economic activities have been slow, with 2012 growth being forecast to drop to 1.4 per cent from 2.1 per cent in FY2011. Despite a pick up in the fisheries and agriculture sectors, the near-term outlook seems cloudy given the declining public sector demand due to Compact grant reduction. Inflationary pressure has been alleviated, but would remain volatile, being subject to fluctuations in the international commodities prices.

The consolidated government balance continued to record modest surplus at around 1 per cent of GDP. The results were uneven across the four states with two states recording deficits equivalent to 1 per cent of state GDP. Public debt remains relatively low at below 30 per cent of GDP, which can be compared against the Compact Trust Fund (CTF) assets amounting to 83 per cent of GDP. However, the insufficiency of the CTF assets to support budget self reliance beyond 2023 and aggravating social security balances will be putting increasing pressure on the budget over the longer term.

On the financial sector, commercial banks - the main financial players in the system - are well capitalized with sufficient liquidity. The level of non-performing loan is low but lending opportunities

\footnotetext{
${ }^{1}$ FSM has 607 islands, occupying a land mass of around $700 \mathrm{~km}^{2}$. FSM gained its independence in 1986 under a Compact of Free Association with the United States.
} 
within the domestic market remain limited with foreign banks placing most of their funds and investments offshore.

\section{Medium-term Challenge and Fiscal Policy Response}

Over the longer term, the reduction in the compact grants disbursement, decreasing population due to continued outward migration and weak private sector growth will pose grave challenges on growth outlook and the public finance.

The FSM authorities agree with the staff recommendations on the strategy to reduce the revenue gap in line with the decline in the annual Compact grant support. They agree with the need to make significant fiscal adjustments over the medium term, as suggested by staff, while the pace of adjustments will be determined based on detailed assessments. In this context, the authorities set up the 2023 Planning Committee under the leadership of President Mori, whose task is to come up with a realistic action plan to address the looming budgetary shortfalls beyond 2023. They agree with the staff recommendation on the need for the government to quickly strengthen the capacity of the Committee by approving its budget.

Headway has been made in garnering broad support from state governments, business sector and the general public on the national government's reform agenda. The authorities have recently conducted the very first conference with its stakeholders and development partners, hosting of which is seen as a breakthrough after many failed attempts. The conference provided a good starting point for the national government to discuss the seriousness of the challenges. The authorities welcomed the favorable outcome of the meeting, in particular the support received from the development partners group that confirmed their willingness to work with the authorities in moving forward the reform agenda. The authorities will keep the momentum to ensure that the forum is followed by concrete action plans with strong engagement from the stakeholders.

On the fiscal front, tax reform initiatives, aimed at enhancing revenue to put public finance on a sustainable level, continued in 2012. A Unified Revenue Authority (URA) has been set up to introduce a net profit tax that will come into effect in October 2013 and a value added tax that will become effective in October 2014. The URA will take over from the national and state revenues authorities. This reform is a big step forward and the national government is working hard with the state governments to establish consensus in adopting the new arrangement. So far, two out of the four states have agreed to the new tax regime. The new arrangement will come into force once all four states sign and agree to adopt the new arrangement. In line with that, the authorities will continue their efforts in strengthening tax administration through staff training and upgrading of IT system.

On the expenditure side, the authorities advise that they will continue their efforts in improving the operational efficiency of current and capital expenditure through better planning and coordination between the national and state governments. On wage spending, the authorities broadly agree that the public wage rates are high compared to some of the regional peers and thus reducing the rates would allow for fiscal savings. Nevertheless, they believe that it is also essential to balance the need 
to provide for appropriate compensation package as part of the efforts to address the challenge of outmigration of skilled workforce offshore. The authorities are also making their efforts to improve social security balance, which include the amendment to Social Security Act regarding adjusting the retirement age to Age 60 and allowing only 50 per cent of benefits until Age 65 .

The authorities agree on the need to strengthen public financial management and to safeguard the benefits of fiscal reforms. They will continue to work with the Pacific Financial Technical Assistance Center (PFTAC) in strengthening and accelerating the reform work in this area.

\section{Financial Sector}

On banking, the authorities will continue to focus their attention on addressing constraints related to collaterals in lending. The outcome of the enactment of the Secured Transaction Act in 2006 has been a step forward in the right direction. As there is a strong need for the long-term loan financing, the authorities will continue to address the land collateral issue.

The Development Bank of FSM provides financing to those sectors supported under the government development priorities and more generally those sectors that are essential but fall outside of the radar of the commercial banks' lending policies. The authorities are well aware of the need to strengthen supervisory oversight over the development bank's operations and will make constant efforts to ensure soundness of the Development Bank.

\section{Private Sector growth}

The private sector development is weak and needs to be strengthened to allow it to support the country's economic growth as the US Compact grant slowly winds down. While noting the small size and remoteness of the country from international markets, the FSM presents a number of competitive advantages in some niche tourism markets, for which the authorities agree on the need to promote and attract inward FDIs.

There are signs of FDI interest in the tourism sector. A recent interest received includes a huge project proposal that presents challenges for the country to accommodate - particularly in the area of land tenure protection rights. An alternative approach would be to attract small-scale FDIs that will generate immediate benefits as it works towards strengthening the country's capacity to attract and support bigger FDIs. Another sector of the economy that has potential is the agriculture sector. The increase in FDIs in the future would highlight the need for locally grown food to be produced to mitigate high volatility of imported food prices. Fisheries sector has also room to grow further, providing greater employment opportunities domestically.

The government will continue its efforts to improve the business environment - particularly reform to ease the cost of doing business. The authorities are committed to devising a nation-wide development plan, building on the momentum created by the first development Partners Forum held in the fall of 2012. An Investors' and Bankers' symposium is now planned for mid-Spring to harness support from both domestic and international lenders for financing of priority development projects. 


\section{Conclusion}

Future prospects look challenging, given the unfavorable global market conditions and the winding down of the US Compact support on which the economy is heavily dependent. Nevertheless, the FSM authorities have been making positive strides in moving forward the much needed reform. The key is in fortifying the support from the state governments and the general public. The authorities reaffirm their strong commitment to the reform agenda, particularly strengthening the public finance and savings towards the 2023 deadline and fostering the private sector to support sustainable economic growth. The FSM authorities will continue to work closely with the Fund in this regard. 